\title{
Dünyada ve Türkiye'de Pandemilerle Mücadele: Risk ve Kriz Yönetimi Bağlamında Bir Değerlendirme
}

\author{
Ahmet TUNÇ * \\ Fatma Zehra ATICI **
}

\begin{abstract}
Öz
Covid-19 salgını küresel çapta insanların ruhsal ve fiziksel sağlığını tehdit eden bir salgın hastalık olarak 2019'un Aralık ayında ortaya çıkmıștır. İnsan sağlığını tehdit etmesinin yanı sıra sosyal yaşamdan ekonomiye, siyasetten uluslararası ilişkilere her alanda değişim ve dönüşümlere neden olmuş, günlük yaşamın normlarına nüfuz etmiştir. Bu yönüyle ortaya çıtığı günden itibaren kısa sürede tüm dünyaya yayılan ve hala etkin bir tedavi ve aşısı olmayan pandemik Covid-19 ile mücadele edebilmek için geçmiş tecrübelerden de referans alınarak salgının her aşaması risk ve kriz yönetimi bağlamında ele alınmalıdır. Bu çerçevede bu çalışmanın amacı salgınla mücadele yöntemlerini risk ve kriz yönetimi açısından ele almak ve mevcut mücadele politikalarına yer vererek daha efektif bir mücadele için politika önerilerinde bulunmaktır.
\end{abstract}

Anahtar Kelimeler: Risk, Kriz, Geçmişte Salgınlar, Covid-19 Salgını, Salgınlarla Mücadele Yöntemleri

\section{Struggling Pandemics in the World and in Turkey: A Study in the Context of Risk and Crisis Management}

\begin{abstract}
The Covid-19 epidemic emerged in December 2019 as an epidemic that threatens the mental and physical health of people globally. In addition to threatening human health, it has caused changes and transformations in every field from social life to economy, from politics to international relations, and has penetrated the norms of daily life. In order to strive pandemic Covid-19, which has spread all over the world in a short time since the day it emerged and still has no effective treatment and vaccine, every stage of the epidemic should be considered in the context of risk and crisis management, taking reference from past experiences. In this context, the purpose of this study is to consider the methods of combating the epidemic in terms of risk and crisis management, and to make policy recommendations for a more effective fight by including existing combat policies.
\end{abstract}

Keywords: Risk, Crisis, Past Epidemics, Covid-19 Epidemic, Methods of Strugglting Epidemic

\footnotetext{
*-Doç. Dr. Ahmet TUNÇ, Çanakkale On Sekiz Mart Üniversitesi, Siyasal Bilgiler Fakültesi, Siyaset Bilimi ve Kamu Yönetimi Bölümü, ahmet.tunc@comu.edu.tr, ORCID NO: 0000-0003-0106-2599.

**-Doktora Öğrencisi, Fatma Zehra ATICI, Necmettin Erbakan Üniversitesi, Sosyal Bilimler Enstitüsü, Uluslararası İlişkiler Anabilim Dalı, fzehra_atici@outlook.com, ORCID NO: 0000-0002-3047-4659.
} 


\section{Gíriș}

İnsanlık, topluluklar halinde yaşamaya başladığı dönemden itibaren tarih boyunca çeşitli salgın hastalıklar, pandemiler ve doğal afetlerle mücadele etmiştir ve etmeye de devam etmektedir. Geçmişte gerek küresel gerekse bölgesel düzeyde yaşanan salgın, pandemi ve doğal afet gibi felaketlerin birçoğunun üstesinden gelmek oldukça zor olmuş hatta çok sayıda insan bu salgınlarda ve afetlerde hayatını kaybetmiştir. Bununla birlikte yaşanan salgın dönemlerinde ülkeler, salgınla mücadele kapsamında bir takım strateji, taktik ve yöntemler geliştirmeye çalışmıştır. Bu noktada yürütülen mücadeleler, alınan önlem ve tedbirler kimi zaman salgın hastalıkların yayılımının önlenmesini mümkün kılmış kimi zamansa yeterli derecede etkili olamamıştır. Öte yandan toplumun her kesimini ruhsal ve fiziksel sağlığın yanında sosyal, kültürel ve ekonomik açıdan da oldukça derinden etkileyen salgın, pandemi ve doğal afetler ile yürütülen mücadeleler günümüze miras olarak kalmışve insanlık için olası felaket durumlarında tekrar başvurulan birikimler olmuşlardır. Burada dikkat çekmek istediğimiz nokta ise, geleneksel toplumlarda ve modern toplumlarda yürütülen mücadelelerin farklı niteliklere sahip olmasıdır. Özellikle tıbbın ve teknolojinin yeterince gelişmediği geleneksel toplumlarda yürütülen mücadelelerin belirsiz kısıtlar içerisinde gerçekleştirilmesi pandemi ve salgınların daha uzun sürmesine neden olmuştur. Günümüzde içerisinde bulunduğumuz modern toplum ise geleneksel toplumlardan farklı olarak bir takım riskler içerisinde yer almaktadır (Beck, 2019). Modern toplumu risk toplumu yaklaşımları içerisinde değerlendirmeye aldığımızda var olan risklerin de tartışılması gerekmektedir Bu bağlamda bir doğal afet türü olan salgınların ve bu salgınlarla mücadele yöntemlerinin, modern toplumun içerisinde bulunduğu riskler nedeniyle risk yönetimi ve kriz yönetimi çerçevesinde ele alınması gerekmektedir. Bu doğrultuda bu çalışmanın konusunu geçmişte yaşanan salgınlar ve bu salgınlarda yürütülen mücadeleler ekseninde, 2019 yılının Aralık ayında, Çin'in Wuhan kentinde ortaya çıkan ve kısa bir süre içerisinde küresel düzeyde yayılım gösteren ölümcül Covid-19 pandemisine yönelik Türkiye’de ve dünyada verilen mücadeleleri risk ve kriz yönetimi bağlamında tartışmak ve sonrasında politika önerilerinde bulunmak oluşturmaktadır.

Çalışma üç ana düzlemde ele alınmıştır. İlk olarak salgın hastalık ayırdımının daha net anlaşılabilmesi için kavramsal çerçeve kısmında endemi, epidemi ve pandemi kavramlarının tanımına yer verilmiştir. Daha sonra risk kapsamında değerlendirilen Covid-19 ile yürütülen mücadelelerde strateji, yöntem ve tekniklerin daha iyi anlaşılması ve belirlenebilmesi için risk, risk toplumu, risk yönetimi ve kriz yönetimi kavramları da kavramsal çerçevede ele alınmıştır. İkinci olarak salgın hastalıkların risk ve kriz bağlamında değerlendirilmesine yer verilerek, salgınla ilgili verilerin risk ve kriz ile ilişkisi açıklanmaya çalışılmıştır. Devam eden bölümde geçmişte yaşanan salgınlar, bu salgınların etkileri ve bu salgınlarla verilen mücadeleler kronolojik sıralamaya uygun biçimde işlenerek bir takım tespitlerde bulunulmuştur. Daha sonra Türkiye coğrafyasında etkili olan salgın hastalıklar ve bu hastalıklarla mücadele yöntemleri kapsamında alınan tedbir ve önlemler tartışılmıştır. Son olarak ise Covid-19 salgınının ortaya çıkış sürecinden başlanarak virüsün neden olduğu toplumsal, siyasal, ekonomik ve psikolojik etkileri ele alınmış ve gerek Türkiyede gerek tüm dünyada yürütülen mücadeleler kriz ve risk 
yönetimi kapsamında değerlendirilerek bir takım politika önerilerinde bulunulmuştur.

\section{KAVRAMSAL ÇERÇEVE}

Salgın hastalıkların tarihi göz önüne alındığında, salgın hastalıkların biyolojik bir olgu olarak geçmişinin insanlık tarihi kadar eski olduğu görülmektedir. Bu saptamanın en temel dayanağını hastalıklara neden olan mikroorganizmaların insanlık tarihinden de eski olduğu kabulü oluşturmaktadır. İnsanların toplu bir şekilde ölümüne yol açan salgın hastalıkların kaynağı olan mikroorganizmalar, gözle görülemeyecek kadar küçük oldukları için varlıkları uzun bir süre bilinememiştir. Bununla birlikte geleneksel toplumlarda var olan yaşam biçimlerini de bu hastalıkların bilinmemesinde rol oynayan etkenlerden biri olarak değerlendirmek mümkündür (K1lıç, 2020:18). Zira yerleşik hayatın olmadığı ve insanların avcılık ve toplayıcılık yaparak yaşamını sürdürdügü geleneksel toplum dönemlerinde herhangi bir salgın hastalığa yakalanma riski düşük olduğundan bu hastalıkların bilinme olasılı̆̆ı da düşüktü. Öte yandan hastalığın yerleşik hale gelmesi ve insanlar arasında bir salgın şeklinde var olması kalabalık insan nüfusu ihtiyacını gerektirdiğinden salgınların uzun dönemli olması da mümkün değildi. Fakat daha sonra yerleşik hayata geçişle birlikte hastalıkların ortaya çıkmasını kolaylaştıran birçok etmen de ortaya çıkmıştır. Dolayısıyla salgın hastalıklar ile ilgili bilinç artmış ve tarihteki salgın hastalıkların adları ve sistematiğinin ne olduğu tartışılmaya başlanmıştır (Dinçol, 1985:5).

Salgın hastalıklar bilimsel yapıları ve özellikleri itibariyle yayılma alanları ve etkiledikleri insan sayısına göre sinıflandırılarak farklı isimlendirmelere tabi tutulmaktadırlar. Bu noktada bir salgın hastalık "endemi, epidemi ve pandemi” olmak üzere dünya üzerinde etkilediği alan ve insan sayısına göre üç şekilde sınıflandırılmaktadır. Eski Yunancada "en” sözcüğü "içinde”, “demos” sözcüğü ise insanlar anlamına karşllık gelmektedir. Bu iki sözcügün birleşiminden türetilen "endemi” belirli bir nüfus içerisinde her zaman var olan ve dışarıdan bir etki olmaksızın belli bir popülasyonda varlığını sürdürebilen bir hastalığı tanımlamak için kullanılan terimdir. Epidemi kelimesi de eski Yunancada "epi” üzerinde ve yine insanlar anlamına gelen "demos" sözcüklerinin birleşiminden türetilmiştir. Bir hastalığın epidemik olarak tanımlanabilmesi için ise belli bir insan popülasyonunda, belli bir zaman dilimi içerisinde görülmesi ve hastalığın önceki tecrübelere göre beklenenden fazla etki göstermesi gerekmektedir. Son olarak pandemi ise eski Yunancada tüm anlamına gelen "Pan" ve insanlar anlamına gelen "demos" kelimesinden türetilmiştir. Pandemi, endemi ve epidemiden farklı olarak bir kıta hatta tüm dünya yüzeyinde yayılan ve etkisini gösteren hastalık anlamına gelmektedir (Ataç ve Uçar, 2006: 33-34). Küresel düzeyde bir etki alanına sahip olan pandemide hastalığın tipik seyri ise şu şekilde işlemektedir: hastalık sağlıklı kişilere kısa sürede bulaşarak yayılır. Hastalık akut ve şiddetli bir biçimde seyreder. Hastalığa yakalananlar kısa sürede ya ölür ya tamamen iyileşir. Son olarak hastalıktan kurtulanlar hastalığa karşı uzun süreli veya yaşam boyu bağışıklık geliştirebilir.

Bulaşıcı bir salgın hastalığın tipik bir döngüsünü ifade eden yukarıda ki adımlar tarih 
boyunca çok sayıda can kaybına neden olmuş ve etkiledikleri bölgelerde derin izler bırakmışlardır. Bu salgınlar kimi kısa kimi de uzun süren ama her seferinde çok sayıda can kaybına yol açan salgın hastalıklar olarak ortaya çıkmış ve insanoğlu da buna karşı tedbirler almaya ve bunların üstesinden gelmeye çalışmıştır. Salgınlar insan toplumlarında can kaybının dışında ekonomik, yönetsel, toplumsal ve siyasal anlamda çok önemli değişimler yaşanmasına yol açmıștır (Turan ve Çelikyay, 2020:3-4). Gerek geçmişte ve yakın geçmişte yaşanan salgınların birey ve toplum üzerinde ki etkileri incelendiğinde, salgınların yalnızca can sağlığını tehdit eden biyolojik olgular olmadığını aynı zamanda hayatın her alanında değişim ve dönüşümlere neden olan hastalıklar olduğunu görmekteyiz. Bu bağlamda salgın hastalıkların neden olduğu değişim ve dönüşümleri anlamlandırmak ve bu süreçte izlenecek yol ve yöntemleri belirlemek hedeflendiğinde, bu hedefi gerçekleştirmek için risk ve risk toplumu kavramlarının gerekli terminolojiye sahip olduğunu görmekteyiz.

En basit tanımıyla "zarara uğrama tehlikesi” (TDK, 2020) olarak ifade edilen risk, başka bir ifadeyle "olası bir kaybın ya da zararın algılanan boyutu" olarak tanımlanmaktadır (Özer, 2011: 332). Risk alanında çalışmalar yapan Ulrich Beck’e göre riskle ilgili olarak dikkate alınması gereken nokta tehlikenin varlığından kaynaklanan olumsuz durumlardır. Beck, 1992 yılında yayımladığ "Risk Society: Towards a New Modernity" isimli eserinde risk ve tehlikenin küresel doğası ve modern sebeplerinin ne olduğu üzerine odaklanmıştır. Küreselleşmenin ve modernleşmenin etkisiyle tehlike ve risklerin daha da arttığ fikrini savunan Beck, risklerin oluşturdukları etkiler bakımından artık doğdukları yerde kalmadıklarını ve doğası gereği küresel düzeyde yaşam formlarının tümünü tehlikeye attığını söyleyerek günümüz modern toplumunun giderek risk toplumuna evirildiğini ifade etmeye çalışmıştır. Özer (2011)'in "salgın bir virüs gibi olan risk insan yaşamının derinlerine nüfuz etmeye başlamıştır” ifadesi de risk toplumuna ilerlediğimizi gösteren ifadelerden biridir. Dolayısıyla bu ifadeden de anlaşılacağı üzere risk belirli bir bölge veya kitle için sınırlı kalmayıp giderek küresel düzlemde tartışılan tehditlerin varlığında ortaya çıkan bir olgu olarak karşımıza çıkmaktadır.

Giddens’ın 1999 yazmış olduğu "Risk” isimli makalede, Beck’e benzer bir yaklaşımla geleneksel toplumlarla modern toplumları risk olgusu üzerinden karşılaştırarak aradaki farklılıkları ortaya koymaya çalışmıştır. Giddens yapmış olduğu çalışmada Beck’ten farklılaşarak, günümüz toplumlarındaki risklerin önceki toplumlardaki risklerden daha fazla olmadığını, ancak risk ile tehlike arasındaki dengesizliğin artmış olması nedeniyle riski bugün küresel düzeyde tartıştığımızı ifade etmektedir. Devamında, kendi üretmiş olduğumuz tehlikelerin dışarıdan gelen tehlikelerden daha fazla tehdit içerdiğini, bir kısmının bizleri bireysel olarak etkilediğini ancak küresel ekolojik sorunlar, nükleer silahların yayılması, dünya ekonomisinin çökmesi gibi risklerin asıl felaketler olduğunun altını çizerek risklerin birçok bilinmezlik/belirsizlik içerdiğini belirtmektedir (Giddens, 1999). Her iki düşünürün de üzerinde durduğu temel konu risklerin küresel bir nitelik taşıdığıdır. Dolayısıyla Covid-19 pandemisi de küresel bir risk haline gelmiş olduğu için salgının risk toplumuna özgü bir nitelik taşıdığı belirtilebilir. Bu noktada salgının yaratmış olduğu etkileri analiz etmek amacıyla risk ve risk toplumu ile beraber risk yönetimi kavramı da son dönemlerde oldukça ön plana çıkan kavramlardan biri olmuştur. 
Risk yönetimi kavramı tanım olarak riskin tamamen engellenmesi değil, sorunlara sistematik ve dikkatli bir şekilde yaklaşılması ve almaya karar verilen risklerin dikkatli yönetimi yoluyla gereksiz kayıpların engellenmesi anlamına gelmektedir (TBD, 2006:5). Risk yönetiminde önemli olan nokta riski iyi tanımak, doğru teşhis etmek, riski bertaraf etmenin yollarını aramak ve riski minimize ederek transfer edebilmektir. Bu bağlamda Covid-19 pandemi sürecinin en az zararla atlatılabilmesi için alınan önlemlerin risk yönetimi bağlamında mutlaka irdelenmesi gerekir. Ayrıca burada risk yönetiminin başarısını maksimize edecek olan kriz yönetimini de göz ardı etmemek gerekmektedir. Zira kriz tanımına baktığımızda, krizin bir kişi, bir örgüt ya da bir toplumun yaşamında görülen zor bir anı yani bir buhran dönemini ifade ettiğini görmekteyiz. Bu yönüyle kriz değerlendirildiğinde kriz belirsizliği, zarar görme olasılığını ve riski kendi bünyesinde barındırmaktadır (Cener, 2007:2). Dolayısıyla risk yönetimi ve kriz yönetimi arasındaki ilişkiye bakıldığında, riskin krizden önce olduğunu ve risk yönetiminin de kriz yönetiminden önce geldiğini ifade etmek gerekir. Bununla birlikte salgın yönetimi açısından risk yönetimi ve kriz yönetimi süreçleri arasında ilişkisel bir döngü bulunduğunu da görmekteyiz. Salgın yönetimi sürecinde tespit edilen risk faktörleri ne kadar azaltılırsa ve olasılıklar ne denli iyi tahmin edilirse, ileriye dönük projeksiyonların belirlenmesinde ne oranda isabet ettirilebilirse, riskleri azaltmak için ne denli önlemler alınıp ona uygun politikalar geliştirilirse krizler ortaya çıktığı andan itibaren de o oranda etkin bir kriz yönetimi süreci sergilenmiş olacaktır (Turan ve Çelikyay Hamza, 2020:7). Bu durumda dünyada ve Türkiye'de salgınla mücadele kapsamında yürütülen faaliyetlerin başarıyla uygulanması, sürdürülmesi ve etkili sonuçlarının alınabilmesi için salgının risk ve kriz yönetimi bağlamında kaçınılmaz olarak değerlendirilmesi gerektiğini ifade etmemiz gerekir. Bununla birlikte risk ve kriz yönetimi planlaması yapılırken tarih ve geçmiş deneyimleri de göz önüne almak, atılan stratejik adımlardan biri olacaktır. Dolayısıyla biz de çalışmamızda salgının yönetimi açısından öncelikle risk ve krizi değerlendirme sürecini tanımlayacak daha sonra risk ve kriz yönetiminin hem geçmiş salgınlarda ne denli etkili olduğunu araştırmak hem de salgınla mücadele yöntemlerine politika önerilerinde bulunabilmek amacıyla tarihsel seyir içerisinde yaşanan salgınlar ve bu salgınlarda yürütülen mücadele yöntemlerine yer vereceğiz.

\section{RİSK VE KRİZİN SALGIN AÇISINDAN DEĞERLENDİRİLMESI}

Genel olarak risk kavramı kendi içerisinde belirsizlikleri de barındıran bir kavram olarak karşımıza çıkmaktadır. Herhangi bir durum karşısında, durumun sonuçları hakkında olasılık dağılımlarının istatistikleri çıkarılabiliyorsa risk, bu konu hakkında ortak bir tutum sergilenemiyorsa belirsizlik söz konusudur (Özer, 2011:337). Risk kavramının içerdiği belirsizlik nedeniyle bir konu hakkında istatistiksel çıkarımların yapılamaması, yapılsa dahi yinelenebilir risk durumlarının belirsiz oluşu bu konu hakkında karar verme ve planlama açısından öngörü eksikliğine neden olmaktadır. Dolayısıyla var olan her belirsizliğin de risk yönetimi kapsamında değerlendirilmesi gereken önemli noktalardan biri olduğunu söylemek gerekir. Klasik risk analizi yaklaşımlarında da karar vericilerin 
gelecekteki olası sonuçlara göre, belirsizliği de analiz kapsamına alarak duruma bütüncül bir bakış açısıyla yaklaşması gerektiği ifade edilmektedir (Köse, 2007:43).

Risk analizinde risklerin belirlenebilmesi için öncelikle risk öncesi bir tarama sisteminin oluşturulması gerekmektedir. Tarama sisteminde yürütülen faaliyetler kendi içerisinde etkin bir kriz yönetimini de gerektirmektedir. Zira risk yönetiminde hedef, riskin ortadan kaldırılması değil, riski yaratan tehlikelerin olası bir kriz anında zararın en aza indirilerek krizin aşılmasıdır (Tunç vd., 2018). Bu sebeple risk analizinde izlenecek yolları belirleme aşamasında kriz yönetimine başvurmak gerekmektedir. Nitekim risk analizi yaklaşımlarında riski analiz etmede belirlenen tarama sistemindeki adımlar da kriz ve kriz yönetimi ile ilişkilendirilerek belirlenmiştir. Risk analizini mümkün kılan tarama sisteminde belirlenen adımlar ise şu şekildedir (Özer, 2011:338) :

- Sorun Yönetimi: Var olan sorunun çözümü risk altında bulunanları etkileyecek problemin bir türü olarak değerlendirmeye alınır. Sorun yönetimi adımında sorun yönetimi ile sorunun olumsuz etkileri azaltılmaya çalışılır. Bu doğrultuda sorunlar neden olacakları etkiler kapsamında kısa ve uzun dönemli şeklinde ayrıștırılmalıdır. Bazı sorunlar uzun veya kısa dönemde krize neden olabilecekleri için bu sorunlar için kriz taramasının da yapılması gerekmektedir.

- Risk Değerlemesi: Burada risk faktörleri tanımlanarak krize neden olabilecek zayıflıklar tespit edilir. Dolayısıyla olası kriz durumları tespit edilmeden önce zayıflıkların giderilmesi adına bir takım önlemler alınmalıdır.

- $\quad$ Risk Altında Bulunan Gruplarla Olan İlişkiler: Risk durumlarında, bu riskin sahip olduğu tehlikelerden en çok etkilenecek olan gruplar tespit edilmeli ve bu gruplarla iletişim halinde olunmalıdır. Bu gruplarla yapılan iletişim en çok kriz anlarında faydalı olacaktır. Zira kriz öncesi bilinçlendirme ile kriz anında yaşanacak olan panik durumlarının ve bu durumların yaratacağı yeni risk ve krizlerin de önüne geçilmiş olacaktır.

Yukarıda ki adımların belirlenmesiyle oluşturulan risk tarama sistemi, risk belirleme sürecini daha somut ve planlı hale getirecektir. Risk tarama sisteminin uygulanmasında ise riskin tanımlanması, riskin ölçülmesi, riskin yargılanması, riskin değerlendirilmesi ve son olarak risk analizi adımları takip edilerek başarılı bir risk yönetimi süreci izlenmelidir. Risk yönetimi sürecinde en temelde tehlikenin tanımı, kontrolü ve kaydı, fırsatların tanımı, kontrolü ve kaydı, risklerin minimize edilmesi, kazançların maksimize edilmesi, kayıpların önlenmesi ve azaltılması, kazançların optimize edilmesi, krizin etkin bir şekilde yönetilmesi ve son olarak maksimum yönetim kapasitesine ulaşılması hedeflenmektedir (Özer, 2011:346). Risk yönetim sürecini, yukarıda saydığımız adımlar doğrultusunda genel başlıklar halinde şematik olarak ifade edecek olursak aşağıdaki adımlar karşımıza çıkacaktır. 


\section{Şekil 1.1. Risk Yönetimi Süreci ${ }^{3}$}

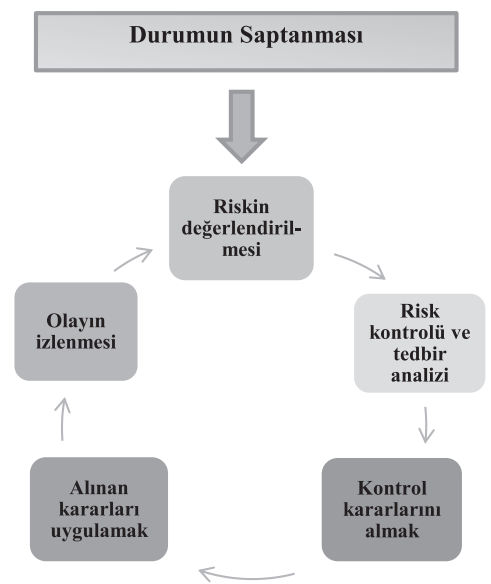

Risk yönetimi süreci ile ilgili şekil 1.1'de verilen adımlar doğrultusunda bir bulaşıcı hastalık salgını durumunda öncelikle durumun saptanması gerekir. Durumun varlığı ile ilgili belirsizliğin ortadan kaldırılması daha sonra atılacak adımların belirlenebilmesi için öncelik taşımaktadır. Durum saptandıktan sonra risk değerlendirmesinde bulunulurken, hastalığın zararı (etkisi), toplumda etkenle karşılaşma oranı ve toplumun duyarlılığı dikkate alınmalıdır. Bununla birlikte risk altında bulunan nüfus veya gruplar kimdir? Risk değerlendirmesinin yapıldığı düzey hangi seviyededir (yerel, bölgesel, ulusal...)? Risk değerlendirmesi aşamasını yürütecek olan kişiler kimlerdir? ve Risk değerlendirmesinde belirlenen zaman dilimi nedir? gibi iyi tanımlanmış sorulara yanıt aramak salgın sürecinde risk değerlendirme aşamasının daha sistemli yürütülmesini sağlayacaktır (İnandı vd. 2020:30).

Risk değerlendirme aşamasından sonra gelen risk kontrolü ve tedbir analizi riskin yönetilmesi için hayati derecede önem taşımaktadır. Zira bu aşamada riski azaltan, indirgeyen veya ortadan kaldıran araç ve kesinleşmiş stratejiler tespit edilmektedir (Cadaloğlu, 2000:8). Bu aşamada geçmişte yaşanan salgınlardan elde edilmiş veriler doğrultusunda bir takım yöntemleri tespit etmek gerekmektedir. Bununla birlikte alınacak olan kararların niteliği kapsamında alanında uzman kişilerden oluşturulmuş bir ekibin kurulması, yürütülecek strateji ve taktikleri belirlemede önem arz etmektedir. Zira alanında uzman olmayan kişilerin karar aşamalarında etkili olmaları yeni risk durumlarını beraberinde getirecektir. Bu aşamayla ilgili olarak belirtmemiz gereken bir diğer husus, günümüzün teknoloji ve iletişim ağından yararlanarak toplumun tüm kesimlerinin belirlenen tespit ve stratejilerden haberdar olmasını sağlamaktır. Ayrıca bu süreçte toplum psikolojisi iyi gözlemlenmeli, var olan kötü şartlar en iyi şekilde iyileştirilmeye çalışılmalı ve toplumdaki hiçbir bireyin yalnız olmadığı ve bu zorlu sürecin üstesinden birlikte

3- Bu şekil araştırmacılar tarafından oluşturulmuştur. 
aşılacağı mesajı yansıtılmalıdır. Etkin bir medya kullanımını gerektiren bu adımlar sahip olunan bilginin de doğru ve kontrollü yönetilmesini gerekmektedir.

Riski kontrol altına almayı sağlayan araç ve yöntemler ise üçüncü aşamada tüm belirsizlik, olasılık ve kesinlik durumları göz önüne alınarak belirlenir ve bir sonraki aşamaya geçmek için bu kararlar alınır (Emhan, 2009:211). Alınan kararlar uygun düzeyde karar veren yöneticiler tarafından alınır ve tüm maliyet ve faydaların analizi yapılarak kontrol kararlarını alma süreci başlatılır (Özer, 2011:347).

Dördüncü aşama olarak belirlenen alınan kararları uygulama aşamasında ise zamanı ve kaynakları iyi kullanarak belirlenen ve geliştirilen stratejiler uygulanmaya başlanır. $\mathrm{Bu}$ aşamada kararların uygulanabilmesi için karar alıcılar ve risk grubu arasında daha önceden iyi bir iletişimin kurulması gerekir. Daha önceki aşamalarda risk grubunda bulunan kişilere alınan kararların doğru bir şekilde ulaştırılması, risk grubundan beklenen tutumların iyi ifade edilmesi ve risk grubunda ki herkesin yüksek katılımının sağlanması gerekmektedir. Çünkü alınan kararların uygulanma aşaması risk yaratan tehlikenin ortadan kaldırılmasını, tehlikenin etkilerinin azaltılmasını veya tehlikeden en az sayıda kişinin etkilenmesini sağlayacak olan aşamadır. Dolayısıyla bu aşamada yürütülecek faaliyetler üst düzey bir koordinasyon ve uyum gerektirmektedir.

Alınan kararların başarılı bir şekilde uygulanması aşamasından sonra yapılacak şey ise olayın izlenmesidir. Olayın izlenmesi aşamasında aksaklıklar tespit edilmeli, bu aksaklıklar giderilmeye çalışılmalı, sürecin devamlılığı için risk grubunda bulunan kişilerin kararları uygulamaları için teşvik edilmeleri ve sürecin kontrol etkinliğinin sağlanması gerekmektedir (Cadaloğlu, 2008:8). Daha sonra uygulanan kararlar sonrası oluşan yeni durumlar için tekrar bir risk değerlendirmesi yapılarak aynı süreç tekrar edilmelidir (Cadaloğlu, 2008:12).

Başarılı bir risk yönetimi sürecinin işletilebilmesi için yukarıda ifade ettiğimiz beş aşamanın gerekliliklerine uygun olarak yerine getirilmesi gerekmektedir. Ayrıca Risk yönetimi sürecinde etkin rol alan kişi veya grupların bu aşamalar içerisinde "gereksiz risk kabul etmeme, risk kararlarını uygun seviyede alma, faydalar maliyetlerden fazla olduğu zaman riski kabul etme" gibi bir takım faktörlere de dikkat etmesi gerekmektedir (Emhan, 2009:216-217).

Risk, kriz, risk yönetimi ve kriz yönetimi açısından salgın hastalık durumlarını değerlendirdiğimizde: genel olarak salgın hastalık durumlarında riskin, bulaşıcı hastalığın salgın yapma olasılığı ve hastalığın etkisinin bir kombinasyonu olarak karşımıza çıktığı söylenebilir (İnandı vd., 2020:28). Kriz ise birden bire ortaya çıkan, önceden öngörülemeyen, beklenmedik ve olağan dişı bir durumu ifade etmektedir (Sezgin, 2003:182). Bu açıdan bakıldığında sağlık çevreleri tarafından tanımlanamayan salgınların da bir kriz durumunu yarattığını ifade etmek gerekir. Ayrıca risk aynı zamanda içinde bulunulan ülkenin/ bölgenin koşullarına, politik duruma, medya ve toplumun risk algısı ve ilgisine bağlı olarak değişebilmektedir. Öte yandan kriz durumları 
da kitlelerin algısına yönelik olarak şekillenmektedir. Krizin büyüklügü, yarattı̆̆g tehdit algısı içerisinde ortaya çıktığı toplumun yaşam deneyimlerinden etkilenmektedir. Bu sebeple krizlerin ortaya çıkma olasılığı, yaratacağı etki, etkileyeceği gruplar gibi olasılıklar risk değerlendirmesinde bulunulurken dikkate alınmalıdır. Bilinmeyen/tanımlanmamış salgın hastalık ile mücadele kapsamında risk değerlendirmesinin amacı ise, acil durum müdahalelerini etkinleştirmek, hastalıkla ilk karşılaşıldığında özgül bir tedavisi ve aşısı olmayan hastalığa özel olarak ilaç dışı halk sağlı̆̆ı önlemleriyle salgını sınırlandırılmak ve etkisini hafifletmektir. Bu bağlamda risk analizinin/değerlendirmesinin yapılması, olayın saptanması ile başlayarak kontrol altına alınmasına kadar devam eden bir süreci ifade etmektedir (İnandı vd., 2020:28-29). Dolayısıyla yukarıda bahsettiğimiz risk analizi yaklaşımındaki risk tarama sistemi adımlarının sistemli bir biçimde risk yönetimi sürecinde stratejik olarak yürütülmesi gerekmektedir. Ayrıca risk analizi kapsamında tarama adımlarıyla yürütülen risk değerlendirmesi, disiplinler arası bir yaklaşım ile konunun uzmanları tarafından ve toplumun da sürece katılımıyla gerçekleştirilmelidir. Öte yandan risk analizi ve değerlendirmesi yapılırken kriz ve kriz yönetimi konuları da göz ardı edilmemelidir. Risklerin var olduğu durumlarda krizlerin de ortaya çıkma olasılığı yüksek olduğundan durum tespit ve saptamalar kriz yönetimi bağlamında da ele alınmalıdır.

Risk yönetimi içerisinde kriz olasılıklarının tespit edilmesi ve sürecin başarılı bir şekilde sonuca ulaştırılabilmesi için sorulması gereken sorular ise şunlardır (Cener, 2007:5): Durumun kritik seviyesi nedir? Olabilecek en kötü şey nedir? Bu karmaşanın ana etkeni nedir? Alternatif çözüm yolları nelerdir? Bu durum en fazla kimleri, hangi grupları etkileyecek? Bu durumdan etkilenecek olan gruplardan kriz süresince beklenen tutum nedir? Olması beklenen durumlarda izlenecek yol nedir? Sürecin yönetiminde kimler rol almalıdır? Bu sorulara verilen cevaplar doğrultusunda belirlenen stratejik yöntem ve taktikler risk yönetimi ve kriz yönetiminin ilişkiselliği içerisinde uygulanmalıdır.

Risklerin ve krizlerin salgın açısından değerlendirilmesi başlığı altında önemle vurgulanan konulardan biri de, yapılan risk analizi sonuçlarının paylaşılması; yani saptanan riskin -iyi- iletişimidir. Değerlendirmenin her aşamasında riskin yorumlanması ve taraflarla paylaşılması gerekir. Riskin iletişimi veya uygun bir dille paylaşımı, halkın alınacak önlemlere hazırlanmasına ve katılımın artmasına yardım edeceği gibi, laboratuvar tabanlı test geliştirme, tanı, izlem ve tedavi için protokollerin hazırlanmasına da rehberlik etmektedir (Turan ve Çelikyay, 2020: 6-7).

Risk, kriz yönetimi ve değerlendirme süreçleri, akut bir halk sağlığı olayını yönetmek için güncel bilginin sürekli ve düzenli olarak toplandığı, değerlendirildiği ve kayıt altına alındığı üç bileşenden oluşan bir süreç olarak tanımlanmaktadır. Bu bileşenleri tehlike değerlendirmesi, maruz kalma değerlendirmesi ve bağlam değerlendirmesi olarak üç genel başlıkta ifade etmek mümkündür. Salgın hastalık açısından tehlike değerlendirmesi kapsamında salgın virüsü insanlarda hastalık yapıyor mu, hastalığın klinik bulguları nelerdir, hangi özellikteki insan gruplarını etkilemektedir, daha önce görülmüş bir hastalık mı, hastalığın yayılmasında özel nedenler var mı, hastalığa hangi bulgular sonucunda 
tanı konulabilir ve son olarak hastalığın etkin tedavi yöntemi var mıdır? Sorularına cevap aranmaktadır. İkinci olarak maruz kalma değerlendirmesinde yanıt aranan sorular ise şunlardır: hasta olan kişi sayısı kaçtır, hastalığın bulaşma yolları nelerdir, hastalığın bulaşıcılık düzeyi nedir, hastalık hastada ne gibi etkilere neden olmaktadır, hastalığın neden olduğu etkiler kalıcı veya geçici hasara neden olabilir mi? Son olarak bağlam değerlendirmesi yapılırken, yerel-bölgesel-ulusal ve küresel düzeyde hastalık ne gibi etkilere sahiptir, hastalığın bulunduğu çevrede toplumun hastalığa karşı duyarlılığı ne durumdadır, toplumdaki bireylerin sağlık davranışları ve kültürel davranışları hastalık durumunu nasıl etkiler? şeklindeki sorulara yanıt aranmaktadır.

Bir salgın hastalık durumunda yukarıda saydığımız sorulara aranan yanıtlar ve bu sorulara verilen cevaplar hastalıkla ilgili başarılı bir risk ve kriz yönetimi değerlendirmesini yapmayı mümkün kılacaktır. Bu noktada önemli olan bir diğer konu ise salgına neden olan hastalığın geçmiş dönemde yaşananlarla aynı niteliğe sahip olsun veya olmasın geçmiş tecrübelerden ve birikimlerden ders alarak geçmiş deneyimleri günümüz şartlarına uyarlayabilmektir. Nitekim bu uyarlamaların yapılması en başta risk ve kriz yönetimlerini etkili bir şekilde yürütebilmeyi sağlayacak ana etkenlerden birisidir. Dolayısıyla salgınla mücadele yöntemlerinin kapasitesini arttırmak ve doğru adımların atılmasını sağlamak için yapılmış olan bu çalışmanın devam eden bölümünde doğru politika önerişlerinde bulunabilmek için geçmişte yaşanan salgınların kronolojik sıralamasına ve bu salgınlarla mücadele yöntemlerine değinilecektir.

\section{TARİHTE YAŞANAN SALGINLAR}

Tarihte yaşanan salgınlara bakıldığında tıp bilimine göre insan hayatını etkileyen ve salgın hastalıklara neden olan mikroorganizmaların insanlığın varoluşundan önce yeryüzünde yaşam bulduğu ifade edilmektedir. Tip tarihi ile ilgili bir kitapta bu durum "yeryüzünde insanlar yokken hastalıklar vardı” şeklinde ifade edilmiştir (Özdemir, 2005:15). Öte yandan salgın hastalıklara neden olan mikroorganizmaların bilinen tarihi, insanlığın var oluşundan önceki zamanlara dayanıyor olsa da, salgın hastalıkların bilinmesi ve etkilerinin önüne geçilmesi uzun zaman almıştır. Bunun en temel sebebi ise var olan ilk insan topluluklarının avcı-toplayıcı bir yaşam biçiminde yaşıyor olmalarıdır. İnsanlar arasındaki iletişim ve etkileşimin yoksunluğu salgın hastalığa neden olacak mikropların yayılmasını engellemiş ve bu hastalıkların etki etme oranını düşük düzeylerde tutmuştur. İnsanlığın yerleşik hayata geçmesiyle birlikte artan etkileşim ise salgın hastalığın yayılım seyrini değiştirmiş ve salgın hastalıklarla ilgili bilinebilirlik düzeyi giderek artmıştır. Bununla birlikte tarihi seyir içinde insanlık salgın hastalıkların oluşma sebeplerine farklı anlamlar yüklemiştir. İnsanlar bu hastalıkların Tanrı tarafından kötülük sahibi insanlara gönderilen bir gazap, doğaüstü güçlerin neden olduğu bir cezalandırma veya kötü ruhların yol açtığı felaketler olarak düşünmüştür (Kılıç, 2020: 15). Örneğin Eski Yunan'da aniden ortaya çıkan ve kitlesel ölümlere neden olan salgınlar doğaüstü birtakım güçlerle açıklanmış ve insanlar bu hastalıkların kendi günah ve kabahatlerine karşılık olarak 
verilen tanrının gazabı olduğunu düşünmüşlerdir (Özdemir, 2005: 16; Kılıç, 2020:16). Öte yandan eski topluluklarda hastalığın doğaüstü nedenlere bağlı olduğunu düşünenlerin yanı sıra bu hastalıkların farklı yollar ile bulaşabileceğini keşfedenler de olmuştur. Örneğin Hintliler ve Çinliler bazı hastalıkların hafif aşamasında hasta olan kişilerle kurulan temas sonucunda hastalığın temas eden kişide ortaya çıkabileceğini keşfetmiştir. Bu keşif hastalıkların insandan insana bulaşabileceğini kanıtlayan ve bununla ilgili araştırmaların yapılmasının yolunu açan bir durum olmuştur.

İnsanlığın yerleşik, büyük ve kalabalık toplumlarda yaşamasıyla birlikte ortaya çıkma ve farkındalık oranı artan salgınlar, tarih boyunca milyonlarca insanın zarar görmesine ve bu zararın sonucunda hayatlarını kaybetmelerine neden olmuştur. Salgın hastalıklarla ilgili olarak Diamond (2018:36) hastalığın kendi bünyelerinde bir döngüye sahip olduğunu söylemiştir. Diamond’a göre salgın hastalıklar tek tek birilerinin devamlı olarak hasta olması değil, hasta olan kişilerin hastalığı etrafında ki kişilere bulaştırdığı ve çok kısa bir sürede nüfusun büyük bir bölümünü etkisi altına aldığı hastalık türü olarak tanımlanmaktadır. Ayrıca salgın hastalıkların bir diğer özelliği akut olarak seyretmeleri ve nihayetinde kısa bir zaman zarfında ölümle veya iyileşme ile sonuçlanmalarıdır (Diamond, 2018:236). Salgın hastalıklar sahip olduğu bu özellikler nedeniyle, ortaya çıktığı toplumlarda siyasal, sosyal, ekonomik, kültürel ve psikolojik açıdan oldukça büyük yıkımlara neden olmuştur. Yapılan araştırmalara göre eski çağlardan günümüze kadar tüm toplumsal düzeni etkileyen yaklaşık üç büyük veba, yedi kolera ve 10'dan fazla grip pandemisi meydana gelmiştir. Epidemik boyutta kalan çiçek, sarı humma ve sıtma hastalığı salgınları da neredeyse yukarıda saydığımız pandemiler kadar yıkıcı etkilere sahip olan hastalıklar olarak ortaya çıkmışlardır (TÜBA, 2020:21).

Geçmişte ortaya çıkan hastalıklar incelendiğinde yukarıda da ifade ettiğimiz gibi siyasal, sosyal, ekonomik ve psikolojik düzeyde, insanlar ve onların kurdukları sistemler etkilenmişlerdir. Salgın hastalıklar savaşların dahi seyrini değiştiren, güç ve düzen değişikliklerine neden olan büyük etkileriyle var olagelmişlerdir. Tarihteki savaşlar incelendiğinde salgın hastalıkların birçok savaşın sonucunu değiştirdiğini, imparatorlukların yıkılmasına neden olduğunu ve hatta devletlerin bir savaş stratejisi olarak bu salgınları kullandıklarını görmekteyiz (Diamond, 2018:253). Nitekim Peleponnessos savaşları, salgın hastalıkların savaşların sonuçlarına etki ettiğini gösteren en popüler örneklerden biri olarak karşımıza çıkmaktadır (Hays, 2005:1). Thucydides (2019:118) Peleponnessos Savaşları sırasında var olan ve savaşın seyrini Atinalılar aleyhine değiştiren hastalığın şiddetini şu sözleri ile açıklamıştır: "Hastalık öyle şiddetliydi ki kimse ne olacağını bilmiyor, tanrısal ve saygıdeğer her şeye karşı saygı kaybediliyordu”. Nitekim savaş esnasında Atinalıların devlet adamı Perikles bile salgın hastalık nedeniyle hayatını kaybetmişti. Bununla birlikte salgın hastalıklar savaş sonuçlarını etkilemenin yanı sıra ordu örgütlenmelerini ve şehir ve kale mimarilerinin yapılanmalarını da etkilemiştir (Özdemir, 2005: 4). Örneğin Roma İmparatorluğunda askeri sıhhiyenin görevi yalnızca savaşlarda yaralanan askerleri tedavi etmek değil, aynı zamanda salgın hastalıkları tedavi etmek ve yayılmasını önlemek de sıhhiyenin görevleri arasında sayılmaktadır. Bununla birlikte salgın hastalıkların iktisadi ve ticari hayatta önemli aksaklıkların yaşanmasına, 
mal ve hizmetlerde artan pahalılığa, insanların toplu göç yapmaları ile yaşanan toplumsal karışıklık ve düzensizliklere de yol açtığı tahmin edilmektedir. Ayrıca geçmişte yaşanan salgın hastalıkların yol açtığı ölüm oranları diğer hastalıkların neden olduğu ölüm oranlarına göre oldukça yüksek düzeyde olmuştur. Bu durumun en temel sebepleri ise karşılaşılan hastalık ile ilgili ön tanımın yapılamaması, hastalığın kaynağının tespit edilememesi, edilse dahi bulaş yollarını yeterince önleyecek araçlara sahip olunmaması ve neticede teknolojinin bugünkü kadar gelişmemiş olması olarak sıralanabilir.

Tarihte yaşanan büyük epidemi ve pandemiler kronolojik olarak sıralandığında ilk olarak M.Ö.429-426 yılları arasında meydana gelen ve Yunanistan'da 75.000 ile 100.000 arasında ölüme sebep olan Atina Vebası karşımıza çıkmaktadır. Bu salgın Atina Şehir Devleti ve Spartalılar arasında yaşanan Peleponnessos Savaşının ikinci yılında ortaya çıkmış ve savaşın seyrinin değişmesine neden olmuştur. Atinalılar tarafından zafer beklenirken, büyük ihtimalle tifüs ya da tifo hastalığı olduğu düşünülen salgın hastalık Atinalıların savaşı kaybetmesine neden olmuştur (Günata, 22.09.2020, https://arkeofili.com/ ). Bununla birlikte salgın Atina halkında kanunlara ve dini inanca bağlılı̆̆ın azalmasıyla sonuçlanan ciddi etkiler bırakmıştır.

165-180 yılları arasında meydana gelen bir diğer salgın ise Antoninus vebası olarak adlandırılan, çiçek ya da kızamık hastalığı olduğu tahmin edilen salgındır. Bu salgın Yakın Doğu'daki seferden dönen askerler tarafından Roma İmparatorluğuna getirilmiştir. Salgın Roma'da günde 2000 kişinin ölmesine neden olmuş ve toplamda beş milyon civarı insanın hayatını kaybetmesine neden olmuştur (Hays, 1998:11). Roma İmparatorluğunun gücünü önemli ölçüde azaltan ve dünya tarihine yön veren bu salgın Hristiyanlığın popülerleşmesine de katkı sağlamıştır.

Daha sonra 541-542 yılları arasında 1. Veba Salgını olarak bilinen ve Avrupa'da 25-50 milyon arasında insanın ölümüne neden olan Justinianus Veba Salgını meydana gelmiştir. Daha sonra periyodik olarak tekrar eden ve dünya nüfusunun yaklaşılk \%10’unun yok olmasına neden olan bu salgın ortaya çıktığı dönemde Bizans İmparatorluğunun düşüşe geçmesine yol açmıştır. Adını dönemin Bizans İmparatoru olan Justinianus'tan almıştır. Bu dönemde Bizans İmparatorluğu Orta Doğu'dan Batıya en geniş boyutlarına ulaşmıştır. Fakat salgının başlamasıyla birlikte Bizans gücünü kaybetmeye başlamış ve elde ettiği topraklardan geri çekilmeye başlamıştır (Jarus, 22.09.2020, https://www.livescience.com/).

Tarihte yaşanan diğer bir önemli veba salgını ise Kara Ölüm olarak adlandırılan 13471351 yılları arasında etkili olan fakat yaklaşık 400 yıl boyunca çeşitli zamanlarda farklı varyasyonları ile ortaya çıkan ve yaklaşık 75 milyon insanın ölümüne neden olan salgındır. Dünya çapında büyük bir pandemiye neden olan salgın hastalık Orta Doğu, Yakın Doğu, Uzak Doğu, Hindistan, Çin, Avrupa, Afrika ve Rusya'da milyonlarca insanın ölümüne neden olmuştur. Dünya genelinde büyük yıkımlara neden olan bu pandemiden sonra dünya ve insanlık tarihinde değişim ve dönüşümler yaşanmış gerek sosyal hayatta gerekse ekonomik hayatta farklı bir döneme girilmiştir (Özdemir, 2005: 22-23). 
Yıkıcılığı ve hastalığın önüne geçilemeyişi göz önüne alındığında salgın hastalıkların en önemlileri arasında sayılan veba hastalığının tarihi incelendiğinde, bu hastalığın tarih boyunca pandemi, epidemi ve endemilere neden olduğu görülmektedir. Dolayısıyla zaman zaman kendiliğinden ortaya çıkan ve insanlara rastlantı sonucu bulaşan vebanın salgın hastalıklar tarihinde önemli bir yeri vardır. Nitekim dünya tarihinde yaşanan salgın hastalıklar ile ilgili yapılan çalışmaların genel olarak veba salgınları, kolera salgınları ve grip salgınları üzerinde yoğunlaştığını söylemek mümkündür. Bu açıdan değerlendirildiğinde veba salgınlarının yüz yıllar boyu bir geçmişe sahip olduğu ve en çok rastlanan türlerinin de Hıyarcıklı Veba ve Akciğer Vebası olduğu görülmektedir. Veba salgınları 20.yy’ın başlarına kadar dünyada çeşitli pandemilere neden olmuş ve kitlesel ölümlere yol açmış ve insanlar tarafından korkunç bir hastalık olarak tanımlanmıştır (Akyay, 1974:209). Günümüzde veba hala ölüme neden olan bir hastalık olarak devam etmektedir. Fakat değişen yaşam koşulları, şehirlerdeki fiziksel alt yapıların güçlendirilmesi ve sağlık alanında yaşanan gelişmeler hastalığın ortaya çıkma oranını büyük ölçüde düşürmektedir.

20.yy’ın başlarından itibaren ilerleyen tıp bilimi ve teknolojiyle birlikte veba hastalığının neden olduğu ölüm oranları hızla düşerken Kolera tarihsel süreç içerisinde, kitlesel ölümlere neden olan bir diğer hastalık türü olarak karşımıza çıkmıştır. Vibrio Cholerae bakterisinin neden olduğu bağırsak enfeksiyonuna bağlı akut ve şiddetli ishal ile seyreden Kolera hastalığının ilk dönüm noktası 1817 yılında yaşanmıştır (Yılmaz, 2017:31). 1817 yılından önce özellikle Hindistan'da yerleşik yerel bir hastalık türü olan Kolera, bu tarihten sonra hızla ülke dışına yayılmış ve Asya, Avrupa, Afrika ve Amerika'da da görülmeye başlanmıştır. Kolera hastalığının ilk pandemisi 1817 yılında gerçekleşmiş ve daha sonra 1826-1837, 1840-1849, 1856, 1863-1865, 1879-1884, 1891-1896, 1914-1918 y1llarinda olmak üzere toplam 7 büyük pandemiye neden olmuştur. Bu pandemilerde milyonlarca insanın ölümüne neden olan Kolera Anadolu'da da görülmüş ve burada da kitlesel ölümler yaşanmıştır. 20.yy’n ortalarına kadar devam eden kolera salgınları gerek yerel düzeyde gerekse küresel düzeyde milyonlarca ölüme neden olmuştur. Hatta salgınların yaşandığı süreçler esnasında yapılan bazı savaşlarda, hastalıktan ölen insan sayısının savaşta ölen insan sayısından daha fazla olduğu görülmüştür. Kolera salgınları ilk ortaya çıktığı dönemlerde oldukça yüksek oranda öldürücülüğe sahip iken, daha sonra ki yıllarda hastalıkla ilgili bilinebilirliğin artmış olması nedeniyle daha baş edilebilir bir hastalık türü haline gelmiştir. 1923 yılından sonra hastalı̆̆ın Amerika, Batı Avrupa ve Afrika (Nil nehri dışında) yok olduğu söylenmekteyse de özellikle savaşlar nedeniyle yaşam koşullarında meydana gelen bozulma bugün bile hastalık tehlikesinin var olduğunu göstermektedir (Özdemir, 2005: 32; Ayar, 2005:16).

Tarihte yaşanan salgınlar incelendiğinde Veba ve Kolera salgınları dışında kitlesel ölümlere neden olan ve bugün dahi devam eden salgınlardan biri de grip salgınlarıdır. Grip en yaygı genel tanımıyla akut ve ateşli bir solunum sistemi hastalığıdır (Kılıç, 2020:31). Tip biliminde ki adı İnfluenza olan grip A, B ve C virüslerinin neden olduğu bir hastalıktır. Hastalık hafif ve belirsiz geçirilebileceği gibi bazı durumlarda ölüme neden olan komplikasyonlar da geliştirebilmektedir. Grip hastalığının en kötü komplikasyonu ise enfeksiyonun akciğere ulaşmasıyla oluşan pnömnoni/zatürredir. Eski çağlardan beri 
bulaşıcı bir hastalık olan gribin günümüze kadar 10'dan fazla pandemiye neden olduğu ve bunların çoğunun Çin kaynaklı pandemiler olduğu bilinmektedir. Grip veba, kolera, çiçek, kızamık veya sıtma gibi hastalıklardan farklı olarak kısa sürede ölüme neden olan veya insan vücudunda şekil bozukluklarına neden olan bir hastalık değildir. Grip hastalığının en önemli özelliği enfeksiyona neden olan virüsün sürekli olarak mutasyona uğrayabileceği ve bu geçirdiği değişim nedeniyle hastalığın tedavisinin de oluşan değişime paralel olarak değişebileceğidir. Dolayısıyla vücudun tanımadığı virüslerin neden olduğu gripler karşısında tedavinin mümkün kılınması da uzun dönemler alabilmektedir (Kılıç, 2020:31).

Tarihte ilk bilinen grip salgını 1173'te İtalya ve Fransa'yı etkisi altına alan grip epidemisidir. 1580 yılında yaşanan grip salgını ise tarihte ki ilk grip pandemisi olarak kabul edilebilir. Bu salgın Asya’da ortaya çıkmış ve Afrika, Avrupa ve Amerika’ya kadar ulaşmıştır. Daha sonra 1729-1733 yılları arasında Rusyada başlayan bir grip salgını tüm Avrupa'yı etkisi altına almıştır. Daha sonra 1781 yılında Çin'den başlayarak Avrupa ve Amerika'da yayılım gösteren bir grip pandemisi daha yaşanmıştır. Bununla birlikte ulaşım ve iletişim ağının gelişmeye başlamasıyla grip salgınları giderek daha da artmıştır. Nitekim 1830-1831, 1883 ve 1889-1890 yılları arasında üç grip pandemisi daha yaşanmıştır. Bu pandemiler arasında en önemli olanı 1889-1890 yılları arasında Rusya'da ortaya çıkan, daha sonra Avrupa'ya yayılan ve Rus Gribi olarak adlandırılan salgındır (Yolun, 2012:41).

1918 yılına gelindiğindeyse Domuz Gribi olarak adlandırılan ve üç dalga halinde gerçekleşen salgın hastalık yine milyonlarca insanın ölümüne yol açmıştır. Bu dönemde yaşanan salgında sadece Amerika'da dört milyondan fazla insanın öldüğü tespit edilmiştir (Kılıç, 2020:32). Devam eden dönemlerde Çin'den kaynaklandığı tespit edilen ve farklı kıtalara yayılım gösteren üç grip pandemisi daha yaşanmıştır. 1957 yılında Asya Gribi ve 1968-1970 y1lında Hong Kong Grip pandemilerinde dünya genelinde bir milyondan fazla insanın hayatını kaybettiği görülmüştür. Daha sonra bu pandemileri Koronavirüs kaynaklı 2003 yılında SARS (Severe Acute Respiratory Syndrome), 2009-2010 yıllarında ortaya çıan Domuz Gribi, 2015 yılında ortaya çıkan ve hala devam eden MERS (Middle East Respiratory Syndrome) ve son olarak 2020 COVİD-19 Pandemisi takip etmiştir.

Tarihte yaşanan büyük salgınlar ve pandemiler incelendiğinde daha önce de ifade ettiğimiz gibi genellikle Veba, Kolera ve Grip hastalıklarının pandemi şeklinde ortaya çıtı̆̆ını görmekteyiz, fakat bu hastalıklar dışında çıktığı bölgede etkili olan epidemi ve endemiler de insan sağlığını tehdit eden boyutlara ulaşmış ve kitlesel ölümlerin yaşanmasına neden olmuştur. Bu hastalıklar arasından en yaygın olanları Çiçek, Kızamık, Kabakulak, Tifo, Tifüs, HIV/AIDS, Sıtma, Humma ve EBOLA gibi hastalıklardır.

Sonuç olarak insanlık tarih boyunca gerek yerel düzeyde gerek küresel düzeyde salgın hastalıklarla mücadele etmek durumunda kalmıştır. Bu hastalıklar çoğu zaman savaş gibi durumlardan bile daha yıkıcı etkilere neden olmuş ve bu hastalıkların önüne geçmek, hastalığı önlemek veya hastalıktan kurtulmak mümkün olmamıştır. İnsanlar ve hükümetler hastalık ile karşılaşıldığında bir takım mücadele yöntemleri geliştirmiş 
ve bu yöntemler ile hastalığı ya tamamen ortadan kaldırmayı ya da etkilerini azaltmayı hedeflemişlerdir. Tarih boyunca yürütülen mücadele yöntemleri benzer hastalıklarla karşılaşıldığında kullanılmış ve teknoloji ve bilim geliştikçe bu mücadele yöntemleri de daha kapsamlı hale gelmiştir. Dolayısıyla biz de çalışmamızda bu mücadele yöntemlerinin neler olduğuna değinerek bugün maruz kaldığımız COVİD-19 Pandemisinin üstesinden gelmenin yollarını araştırmış olacağız.

\subsection{Tarihte Yaşanan Salgınlarla Mücadele Yöntemleri}

Salgın hastalıklar ile ilgili yapılan çalışmalar incelendiğinde, hastalık tanılarıyla ilgili oldukça geniş bir literatürün var olduğu görünmektedir. Salgın hastalıklar gerek tıp bilimi içerisinde gerek hastalığın etki alanları doğrultusunda hastalığı araştıran diğer bilimler çerçevesinde hastalık etkeni, ortaya çıkma sebepleri, bulaşma yolları, etkileri ve sonuçları geniş bir şekilde tartışma alanı bulmaktadır. Bu salgın hastalıklar ile ilgili mücadele yöntemlerine baktığımızda ise geçmişten günümüze kronolojik olarak mücadele yöntemlerinin geliştiğini görmekteyiz. Örneğin hastalığa özgü ilaç ve tedavi geliştirmenin mümkün olmadığı yani modern tıbbın gelişmediği dönemlerde insanlar ilk olarak bitkilerden elde edilen şifa yollarına başvurmuşlardır. Alternatif tıbbın her türlüsünün aktif bir biçimde kullanılması kimi zaman hastalıkların tedavi edilmesinde etkili yöntemler olarak karşımıza çıkmaktaysa da kimi zaman dogmatik bilgiler doğrultusunda yürütülen tedavilerin yarardan çok zarara neden olduğu da görünmektedir. Fakat özellikle Veba ve Kolera gibi hastalıklar için çeşitli yiyecek, içecek, ot ve baharat reçeteleri bu hastalıkların tedavi edilmesinde sıklıkla başvurulan ve olumlu sonuçlar doğuran bir tedavi yöntemi olmuştur.

Daha sonra modern tıp biliminin gelişmesiyle birlikte salgınlarla mücadele yöntemleri de gelişmiş ve çeşitlenmiştir. Öte yandan bitkiler ile yapılan tedaviler de kullanılmaya devam etmiş, bitkilerin özü ilaç geliştirme çalışmalarında kullanılmıştır. Genel olarak bakıldığında salgın hastalıklarla mücadelede en etkili stratejiler içerisinde hastalığın etkenine göre değişmekle birlikte karantina, kordon uygulamaları, izolasyon, dezenfeksiyon işlemleri, aşılama, hastalığın kaynağının bulunması, erken tanı devamında tedavi yöntemleri, hastalığın takibinde elde edilen bulguların tedavide kullanılması sayılabilir. Salgın hastalıklarla mücadele yöntemlerinden olan karantina, kordon ve izolasyon yöntemleri birbirlerine benzer uygulamalar olarak görülse de her birinin hedef kitlesi ve ortaya çıkardığı etkisi farklıdır. Örneğin karantina hastalığın küresel dolaşımını engelleme noktasında etkili bir mücadele yöntemi olarak karşımıza çıkarken, kordon uygulaması ise hastalığın belli bir yerleşkeden veya mahallinden dışarı çıkmasını engelleyen bir mücadele yöntemidir (Topuz, 2020:300-301). Salgınla mücadele yöntemlerinde karantina uygulamalarına bakıldığında, literatürden elde edilen verilerin milattan öncesine kadar gittiği görünmektedir. Kutsal kitaplar başta olmak üzere mitolojik metinlerde salgın dönemlerinde hastalığa maruz kalan kişilerin nasıl davranması gerektiği, hangi davranış kalıplarını benimsemesi gerektiği ifade edilmiştir. Buradan yola çıkarak karantina 
uygulamalarını ilk uygulayanlar ise İtalyan Deniz Devletleri olmuştur (Topuz, 2020:301). Salgın hastalıklar tarihi incelendiğinde hastalığın en önemli yayılım yerlerinden biri de limanlar olmuştur. Tarih boyunca ticaret yapan gemiler geldikleri ülkelerden veya gittikleri ülkelere hastalık etkeninin taşımışlardır. Dolayısıyla liman kenti olan ülkeler dişarıdan gelen gemilere limanlarda (Arrk, 1991:31-32).

Salgınlarla mücadelede tarih boyunca kullanılan en önemli yöntemlerden biri de dezenfeksiyon işlemleri olmuştur. Dezenfeksiyon işlemlerinde üzerinde durulan en önemli noktalar ise toplumsal hijyen kurallarına uyulması ve sağlıklı su ve kanalizasyon sistemlerinin sağlanması gibi adımlar karşımıza çıkmaktadır. Öte yandan bireylerin sağlıklı, dengeli ve yeterli beslenebilmesi, hastalığın erken tanısının yapılması, tedavi yöntemlerinin uygulanmasından sonra takibinin yapılması ve tüm sağlık kuruluşlarının koordine bir şekilde çalışması adımları da salgınla mücadelede etkin olabilmenin yollarını mümkün kılmaktadır.

Salgınlarla mücadele yöntemleri incelendiğinde çeşitli hastalıklar karşısında yüzyıllardır edinmiş olduğumuz tecrübelerin gelecek salgınlarla mücadele edebilme noktasında başvurulan önemli referanslar olduğunu görmekteyiz. Bir salgın hastalık veya doğal afet durumunda geçmiş tecrübelere başvurmanın yanı sıra günün şartları da göz önüne alınarak farklı strateji ve taktikler geliştirilmelidir.

\section{TÜRKIYE'DE YAŞANAN SALGINLAR VE BU SALGINLARLA YÜRÜTÜLEN MÜCADELE YÖNTEMLERİ}

İnsanoğlunun tarih boyunca karşı karşıya kaldığı doğal afetlerden biri olarak sayılan bulaşıcı hastalıkların coğrafya, iklim koşulları, sosyo-ekonomik koşullar, toplumların kültür düzeyleri ve hijyen alışkanlıkları gibi demografik özellikler ile ilişkisi olduğu bilinmektedir. Dolayısıyla salgın hastalıkların etkiledikleri kişi sayısı, bulaşma hızı veya hayatta kalma oranı gibi özelliklerinin bulunduğu demografik haritaya göre değiştiğini söylemek mümkündür. Bununla birlikte her hastalığın epidemiyolojisi farklılık gösterdiğinden yukarıda saydığımız demografik özellikler arasında hastalığın etkenliğini arttıran durumlar da farklılık gösterebilmektedir. Bu sebeple salgın hastalıkların anatomisi incelenirken bu demografik farklılıkların da göz önünde bulundurulması ve hastalığın ortaya çıktığı ülkede hastalığın yaratacağı tahribatın önüne geçecek önlemlerin bu çerçevede ayrıca değerlendirilmesi gerekmektedir (Arık, 1991:27-28). Tüm bunlar dikkate alındığında tarihte yaşanan salgın hastalıkların Türkiye açısından da değerlendirilmesi gerektiğini düşünmekteyiz. Daha önce de ifade ettiğimiz gibi tarihte üç büyük veba, yedi kolera ve on grip pandemisi tüm dünyayı etkisi altına almıştır. Ayrıca bu pandemiler dışında yerel salgın hastalıklarla da Osmanlı İmparatorluğu ve Türkiye Cumhuriyeti Devleti karşı karşıya kalmış ve bu hastalıklarla mücadele etmek durumunda kalmışlardır. 
Tarihte yaşanan en önemli salgınlar arasında sayılan Veba hastalığı Anadolu topraklarında da görülmüş ve şiddetli salgınlar şeklinde ortaya çıkmıştır. Bu salgınlar Selçuklular döneminde Anadolu'da çeşitli yerlerde veya ülkenin bir kısmında hükümranlık süren Bizans İmparatorluğu (İstanbul), Danişmendliler (Malatya), Artuklular (Mardin), Selçuklular (Konya- Malatya), İnaloğulları (Amid-Diyarbekir) gibi bağımsız siyasi oluşumların merkezlerinde ve diğer şehirlerinde ortaya çıkmıştır (Özdemir, 2005: 23; Arık, 1991:55). Veba salgınları 1429'da Bursa'da, 1492'de İstanbul'da yine 1597 ve 1750 'de İstanbul'da, 1762 y1lında Diyarbakır'da ve 1799-1800, 1812-1816, 1826-1837, 1847, 1849 ve 1869 yıllarında Anadolunun farklı yerlerinde görülmüştür. Bu salgınlarda binlerce insan hayatını kaybetmiş, hastalık nedeniyle toplu göçler yaşanmış ve gerek siyasette gerekse toplumsal hayatta çeşitli değişiklikler yaşanmıştır. Örneğin 1429 yılındaki salgında II. Beyazıd dört ay boyunca İstanbul'dan uzakta yaşamak zorunda kalmıştır (Özdemir, 2005:24). Anadolu topraklarında meydana gelen veba salgınları ile alınan önlemlerin başında ise karantina ve kordon uygulamaları olduğunu görmekteyiz. Özellikle kordon yani sağlık şeridi uygulamasının diğer devletlerle yapılan işbirliği içerisinde yürütüldügü görünmektedir. Nitekim 1718 Pasarofça Anlaşması Osmanlı ve Avusturya imparatorlukları arasında kesin bir sınır hattının varlığını belirlemesinin yanı sıra hızla yayılan vebanın kontrol altına alınması için bir sağlık şeridi olarak kullanılmıştır. Buna göre Avusturya Monarşisi Doğu'da Türk sınırının sağlık denetimini orduya vermiş ve İtalyan tipi bir karantina sistemi kullanarak 1900 km'lik kara sınır hattını kontrol altına almayı başarmıştır (Uludağ, 1938:451). Karantina sistemi ise iki devlet arasında şu şekilde uygulanmaktadır: sınırdan geçmek için gelen yolcular, binek hayvanları ve mallar ayrı bölümlerden geçmektedir. Yolcuların elbiseleri çıkarttırılmakta, elbiseler sahiplerine geri verilmeden önce buhar, 1sıtma ve yıkama yolu ile dezenfekte edilmekte ve gelen yolcular karantinaya alınarak kırk gün kadar bir süre orada bekletilmektedir. Hasta olduğundan şüphelenilen kişiler tecrit edilerek tedavi altına alınmakta ve getirilen mallar da özenle dezenfekte edilmektedir (Uludağ, 1938:451). Salglla mücadelede karantina usulü şehirlerde ve limanlarda da uygulanmış, ayrıca vebadan vefat edenlerin dini törenlerinin yapılmaması gibi uygulamalar da izolasyon ve tecrit kapsamında hayata geçirilmiştir.

Vebadan sonra Anadolu'da görülen bir diğer salgın hastalık ise Koleradır. 1817 yılında ilk kez pandemi şeklinde ortaya çıkan kolera, Türkiye’de de görülmüş ve büyük kayıplara neden olmuştur. İstanbul'da ilk kez 1830-1831 yıllarında ortaya çıkan Kolera daha sonra 1847-1848, 1865, 1872, 1890, 1892 ve 1907 yıllarında da Türkiye'de görülmüştür. Kolera salgınlarının Türkiye’de ortaya çıkmasındaki en önemli etkenin hac döneminde insanların ülkeye giriş çıkışlarıyla bu hastalığı taşımaları olduğunu söylemek gerekir. Özellikle 1893 yılında yaşanan salgında hastalığı taşıyanların hacdan dönen kişiler olduğu ifade edilmektedir (Özdemir, 2005:34). Dolayısıyla bu dönemde hacdan dönenlerin getirebileceği hastalıkların önüne geçmek için bazı konferanslar düzenlenmiş ve bu konferanslarda alınan kararlar hayata geçirilmiştir. Konferanslarda hacdan dönenlerin karantina ve kordon uygulamaları ile toplumsal hayattan izolasyonu sağlanmış ve böylelikle hastalığının önüne geçilmeye çalışılmıştır (Topuz, 2020:303). Ne var ki kolera hastalığı kolay yayılabilen ve sağlıklı olsun veya olmasın bulaştığı kişinin kolay ve hızlı ölümüne neden olabilen bir hastalık odluğu için önüne geçmek kolay olmamıştır. Bununla 
birlikte dönemin şartları da salgının önlenmesini zorlaştıran etkenler olarak ortaya çıkmıştır. Bu noktada öncelikle bazı bölgelerde alt yapının yetersiz ve kalitesiz oluşunun hastalığın yayılımını kolaylaştırdığını söylemek gerekir. Bununla birlikte yaz aylarında yaşanan göçler de hastalığın taşınmasında oldukça etkili olmuştur. Ayrıca sağlık kuruluş ve çalışanlarının ve tedavide kullanılacak ekipmanların yetersiz oluşu da hastalığın yayılma hızını etkileyen faktörlerden biri olarak karşımıza çıkmaktadır. Dolayısıyla bu dönemde Osmanlı Devleti karantina ve kordon uygulamalarının sıkı bir şekilde yürütülmesi için çaba gösterirken öte yandan diğer eksikliklerin giderilmesi için çaba sarf etmiştir (Topuz, 2020:309-310).

Anadolu'da mücadele edilen önemli salgın hastalıklardan biri de sıtma salgınları olmuştur. Nitekim özellikle Ege ve Akdeniz kıyılarında yer alan medeniyetlerin birçoğunun çökmesinde etkili olan sıtma hastalığı medeniyetleri çöktürecek derecede önemli ve etkili olan bir hastalık olarak karşımıza çıkmaktadır (Akdur, 2006:6). Sitma ile verilen mücadele yöntemlerinin ne olduğu araştırıldığında Osmanlı döneminde genelde halka sunulan sağlık hizmetlerinde ve özelde Osmanlı Devleti’nin yürütmüş olduğu sistemli bir politika olmadığ 1 için o dönemle ilgili resmi ve spesifik verilere ulaşmak oldukça zordur. Bununla birlikte tüm dünyada olduğu gibi Anadolu'da da sitma ile büyük mücadeleler verilmiş fakat yayılım hızı ve etkisi oldukça büyük olduğundan sıtma hastalığı ile başa çıkmak oldukça zor olmuştur. Anadolu'da özellikle Kurtuluş Savaşı yıllarında insanlar, savaşın getirdiği yıkıcılığın yanında bir de yaygın sıtma ile mücadele etmek durumunda kalmışlardır (Ünsal vd., 1982). Bu dönemde sitma hastalığı ile mücadele yöntemlerine bakıldığında, özel bir mücadele yöntemi yerine genel anlamda bir mücadelenin söz konusu olduğunu görmekteyiz. Bunun en temel sebebi ise kurtuluş savaşından sonraki dönemde başlatılan ulusal kalkınma seferberliğinin mümkün kılınması için önem verilen eğitimli ve sağlıklı bir ulusun yaratılması çabasıdır. Ulusal kalkınma seferberliğinin önünde bir engel olarak duran sağlıksız bir toplum ve eğitimsiz bir ulusun çağı yakalayabilmesi için, yalnızca sıtmayı önlemeye yönelik politikalar yürütülmemiş aynı zamanda genel anlamda halkın sağlık ve eğitim düzeyini arttıracak politikalar yürütmüşlerdir (Akdur, 2006:6-7). O dönemde kurulan "Modern Tarım Üretim Çiftlikleri” hem halkın kalkındırılması hem de sıtma hastalığının yayılımına neden olan sağlıksız tarım koşullarının iyileştirilmesi adına hayata geçirilen önemli projelerden biri olarak karşımıza çıkmaktadır. Bu doğrultuda sıtma tehlikesinin hala devam ettiği ve hatta Afrika ve Asya kıtası gibi yerlerde sitma hastalığının görüldügü günümüzde, sıtma ile baş etmenin en temel faktörünü gelişen tarım sistemleri, güçlendirilmiş alt yapı sistemleri ve sağlık hizmetlerinin iyileştirilmesi gibi hizmetlerin oluşturduğunu görmekteyiz. Bu doğrultuda Türkiye'de sitma ve diğer bütün salgın hastalıkların önüne geçebilmek için bu çalışmalar olabildiğince efektif biçimde sürdürülmeye çalışılmaktadır.

Anadolu'da görülen ve mücadele edilen bir diğer hastalık ise gripler olmuştur. Grip hastalıkları bilindiği üzere akut ve ateşli bir solunum rahatsızlığı şeklinde seyreden hastalıklardır. Ayrıca gribe neden olan virüslerin güçlü değişim ve direnç yeteneğine sahip olmaları nedeniyle günümüzde de var olan ve ortadan kaldırılması mümkün olmayan hastalıklar olarak karşımıza çıkmaktadır. Tarih boyunca gribal hastalıklar var olagelmiş 
ve bu hastalıklar ile mücadele etmenin en etkili yolu aşılar olmuştur. Aşı ile tedavide hastalığın ortadan kaldırılması hedeflenmemekte aksine hastalığın engellenmesi veya ortaya çısa dahi etkilerinin en az düzeye indirilmesi hedeflenmektedir (Temel, 2012:4). Aşı tedavilerinin yanında bağışıklık güçlendirme, yaşam koşullarının arttırılması, hükümetler açısından sosyal politikaların güçlendirilmesi gibi politikalar da grip salgınları ile verilen mücadelelerin önemli bir boyutunu oluşturmaktadır. Bu doğrultuda günümüzde de grip hastalıklarından biri olan ve henüz aşı ve tedavisi geliştirilmemiş olan Covid-19 pandemisi ile mücadeleler devam etmektedir. Dolayısıla deva eden bölümde Covid-19 hastalığı hakkında genel bilgilere yer verilecek ve sonrasında dünya ve Türkiyede bu hastalıkla yürütülen mücadele yöntemlerine değinilecektir.

\section{COVID-19 PANDEMİII}

Koronavirüsler insan ve hayvanlarda hastalık oluşturabilen, kolaylıkla mutasyona uğrayabilen ve geniş bir virüs ailesini oluşturan RNA virüsleri olarak bilinmektedir. 2019'un Aralık ayına kadar hastalık yapan 6 tip koronavirüs çeşidi olduğu keşfedilmiştir (Dikmen vd., 2020:30; Budak ve Korkmaz, 2020:65) . Koronavirüs (CoV) ailesi virüsleri genel olarak basit soğuk algınlığı seviyesinde belirtiler gösteren virüs türleri olsa da geçmişte 2002-2003 yıllarında Çin’de Ağır Akut Solunum Yetersizliği (SARS-CoV) hastalığına neden olan bir koronavirüs ortaya çıkmış ve bu hastalık özellikle Asya ülkelerinde oldukça önemli sorunlara yol açmıştır. 2012-2013 yıllarında ise ilk olarak Suudi Arabistan'da görüldüğü varsayılan ve yine Koronavirüs ailesinden olan Ortadoğu Solunum Sendromu (MERS-CoV)'da şiddetli rahatsızlıklara neden olan bir hastalık olarak ortaya çıkmıştır (Yin ve Wunderink, 2018:130-131). Bu doğrultuda Koronavirüslerin sadece basit grip rahatsızlıklarına değil şiddetli akut rahatsızlıklara da neden olduğunu söylemek mümkündür. Nitekim 2019'un Aralık ayında ortaya çıkan yeni koronovirüsün de ağır akut solunum rahatsızlıklarına neden olan yeni bir tür virüs olarak ortaya çıktığı bilinmektedir. Ayrıca yapılan araştırmalara göre bu virüsün daha önceki yıllarda ortaya çıkan SARS-CoV virüsü ile benzerlik oranı \%79, MERS-CoV virüsü ile benzerlik oranı ise $\% 59$ olarak tespit edilmiştir. Koronavirüs ailesinin yedinci üyesi olarak belirlenen bu virüsün önceki bilinen virüslerle benzer özelliklere sahip olduğu görülse de gerek hastalık etkeni açısından gerekse bu yeni tip virüse karşı herhangi bir tedavi yönteminin olup olmadığının belirsiz olması açısından bu virüsün diğerlerinden farklılık gösterdiği düşünülmektedir. Dünya Sağllk Örgütü tarafından SARS-CoV-2 (Aslan, 2020:39) olarak adlandırılan bu virüsün neden olduğu hastalığa ilk başlarda 2019 Novel Coronavirüs adı verilmiş daha sonra ise hastalık ismi Covid-19 olarak belirlenmiştir (WHO, 2020).

İlk kez 2019’un Aralık ayında Çin’in Hubei Eyaleti Wuhan kentinde canlı hayvan pazarı olarak nitelendirilen Huanan Deniz Ürünleri ve Canlı Hayvan Toptan Satış Pazarından ortaya çıktığı düşünülen Covid-19 virüsünün en yaygın semptomları arasında yüksek ateş, halsizlik, ve kuru öksürük yer almaktadır (Üstün ve Özçiftçi, 2020:143; Aşkın vd., 2019: 306). Mevsimsel grip ile kıyaslandığında çok daha bulaşıcı ve patojenik olan Covid- 
19 'un tahmini öldürme oranının ise ülkeden ülkeye \%0,5 ve \%5,4 arasında değiştiği görülmektedir (https://coronavirus.jhu.edu/). Virüsün yayılması ise yakın temastaki insanlar arasında öksürük, hapşırık veya konuşmaya bağlı damlacıkların yayılması aracılığıyla gerçekleşmektedir. Ayrıca düşük seviyede de olsa hastalık belirtilerini göstermeyen kişiler (taşıyıcı kişiler) de hastalığın yayılmasına neden olabilmektedir. Daha önceki hastalıklar olan SARS ve MERS ile kıyaslandığında daha hızlı bir şekilde yayılım gösteren Covid-19 hastalığ 1 kısa bir süre içerisinde tüm dünya ülkelerine yayılmış ve bunun sonucunda Dünya Sağlık Örgütü 11 Mart 2020 tarihi itibariyle hastalığı pandemi olarak ilan etmiştir. Hastalığın özelliklerine bakıldığında SARS ve MERS hastalıklarından daha hızlı yayılım göstermesinin yanı sıra neden olduğu ölüm oranında da farklılıklar olduğu görülmektedir. Covid-19, SARS ve MERS’e göre daha düşük düzeyde ölüme neden olmakta fakat bu durum ülkeden ülkeye farklılıklar göstermektedir (Aşkın vd., 2020:306). Bununla birlikte hastalığın şiddeti bulaştığı her insanda farklı derecede ortaya çıkmakta ve en yüksek risk grubunu 65 yaş üstü yetişkinler, kalp rahatsızlığı olan kişiler, astımlı kişiler, obezitesi olan kişiler, HIV karaciğer ve böbrek hastalığı olan kişiler oluşturmaktadır (Aslan, 2020:39). Fakat Covid-19 her ne kadar yüksek risk grubunda olan kişiler için daha tehlikeli olsa da hastalığa neden olan virüsün tedavisi ile ilgili yeterli bilginin henüz elde edilememiş olması her bireyin aslında aynı ölçüde risk grubunda yer aldığını hatırlatmaktadır. Dolayısıyla tüm bireyler ve devletler, Covid-19 ile mücadele kapsamında işbirliği içerisinde olmalı ve hastalığın tedavisi bulunana kadar bu mücadele etkin bir şekilde yürütülmelidir. Nitekim virüs ile karşılaşıldığı ilk günden itibaren tüm devletler bir takım önlem ve tedbirler ile virüsün etkilerini ve yayılımını en aza indirgemeye çalışmış ve bu uğurda çeşitli politikalar yürütmüşlerdir.

Bu bağlamda tüm devletler, uluslararası örgütler ve bireyler küresel düzeyde bir uyum ve işbirliği içerisinde hareket etmeye çalışarak bu hastalığın üstesinden gelmeye çalışmaktadır. Bu doğrultuda çalışmanın devam eden bölümünde dünyada ve Türkiye’de Covid-19 pandemisiyle yürütülen mücadeleler ele alınacak ve bu mücadelelerin yetkinliği tartışılacaktır.

\subsection{Dünyada Covid-19 Pandemisi ile yürütülen Mücadeleler}

Tarih boyunca ortaya çıkan salgınlar bu günden sonra da tüm dünya tarihi boyunca salgınların var olacağını ve insanlığın bu salgınlarla mücadele etmek zorunda kalacă̆ını göstermiştir. Dolayısıyla bir salgının etkilerini azaltmaya yardımcı olmak için önceden planlama ve hazırlık çalışmalarının yapılması oldukça önem arz etmektedir. Nitekim 2016 yılında Amerikan Ulusal Tıp Akademisi’ne bağlı Küresel Sağlık Risk Sisteminin hazırladı̆̆g bir rapor bu çalışmalara örnek olarak gösterilebilecek bir çalışmadır. Bu raporda gelecek yüzyıl içerisinde koronavirüsün de aralarında bulunduğu dört ya da daha fazla sayıda pandemi görülebileceği tehlikesi ifade edilirken ülkelerin bir pandemiye hazırlık için yıllık 4 milyar dolar bütçe ayırması gerektiği de belirtilmiştir. Ayrıca raporda devletlerin ve toplumların pandemi durumuna hazırlıklı olabilmesi için sağlık hizmetleri yönetimi, laboratuvarlar, eczane hizmetleri ve sağlık izleme sistemlerinin yeterli sayıda ve nitelikli alt yapıya sahip olması gerektiği de vurgulanmıştır (Duran, 2020:8). 
Küresel salgın tehlikesine karşı yapılan bir başka çalışma da Bill ve Melinda Gates Vakfı, Dünya Ekonomik Forumu ve John Hopkins Üniversitesi tarafından yapılan "Event 201" başlıklı bir çalışmadır. Bir simülasyon çalışması olan bu çalışmada Brezilya'da bir domuz çiftliğinden çıkacak ve bulaşıcı özelliği çok yüksek olacak olan bir koronavirüsün etkileri değerlendirilmiştir. Bu simülasyon çalışmasında on sekiz aylık bir zaman diliminde 65 milyon insanın hayatını kaybedeceği ve dünya nüfusunun \%80-90'ının bu hastalıktan etkileneceği söylenmiştir. Simülasyonun en önemli bulgusu ise dünyanın böyle bir pandemiye hazırlıklı olmadığı ve küresel sistemin dirençliliğinin pandemik hastalıklara karşı oldukça düşük düzeyde olduğuydu (Duran, 2020:8). Çalışmada elde edilen bu bulgular doğrultusunda ülkelerin krizle mücadele edebilmesi için ciddi hazırlık çalışmalarına ihtiyaç duyulduğu öngörülmesine rağmen Covid-19 pandemisi, ülkelerin yürüttüğü hazırlık çalışmalarının oldukça yetersiz kaldığının bir göstergesi olmuştur. Dünya genelinde kısa süre içerisinde yayılan ve her yaştan grubu etkileyerek günlük yaşamın normlarına dahi etki eden Covid-19 hastalığ gerekse küresel sistemin ve hatta uluslararası örgütlerin ne kadar kırılgan bir yapıya sahip olduğunu göstermiştir. Ülkelerin böylesi bir kırılgan yapıya sahip olmasının en temel sebebi ise yakın dönemde Covid-19 gibi bir pandeminin tecrübe edilmemiş olmasıdır. Ayrıca gerek virüsün ilk çıktığı yer olan Çin Halk Cumhuriyeti’nin verileri şeffaf olarak paylaşmaması gerek Dünya Sağlık Örgütünün virüse dair ciddi bir tavır almada gecikmiş olması ülkelerin bu krizi yönetmede yetersiz kalmasının diğer nedenleri arasında sayılmaktadır (Buzgan ve Güner, 2020:143). Bununla birlikte kriz sürecini zorlaştıran bir diğer konu ise dünya genelinde yayılım gösteren ve günlük hayat akışını etkileyen pandeminin sağlıktan eğitime, siyasetten uluslararası ilişkilere, ekonomiden psikolojiye her alanda birçok belirsizliği de beraberinde getirmiş olmasıdır. Belirsizliklerin tüm alanlarda yarattığ 1 risk pandemi ile her alanda mücadele edilmesinin gerekliliğini ortaya koyarken risk ve kriz sürecine dahil olan belirsizlikler, pandemi ile yürütülen mücadele sürecini olumsuz anlamda etkileyen en önemli nokta olarak karşımıza çıkmıştır. Dolayısıyla ülkeler tüm bu belirsizlikler içinde bir de pandemi ile mücadele stratejisi belirleme noktasında kararsızlar içerisinde kalmıştır.

Dünya genelinde pandemi ile mücadele stratejilerine bakıldığında ülkeler arasında bir ayrım yapmak gerekirse bazı ülkelerin süreci daha iyi yönettiği görülmektedir. Süreci iyi yöneten ülkeler arasında daha önceki salgınlardan tecrübe edinmiş olan devletlerin yoğunlukta olduğunu görmekteyiz. Ülkelerin salgınla mücadele stratejilerinde attıkları adımların öncelikle Dünya Sağlık Örgütünün bireysel korunmaya yönelik belirlemiş olduğu önlemler dahilinde küresel düzeyde de uygulanması kapsamında ele alındığını görmekteyiz. Dünya Sağlık Örgütünün belirlemiş olduğu adımlar ise şu şekilde sıralanmaktadır (Arslan ve Karagül, 2020:7) :

- $\quad$ Enfekte olmuş kişilerle yakın temastan kaçınılması

Ellerin sık aralıklarla en az 20 saniye boyunca su ve sabunla yıkanması veya alkol bazlı dezenfektanların kullanılmasıyla sterilize edilmesi 
- Enfekte olunması halinde mesafenin korunması, öksürürken hapşırırken tek kullanımlık mendil kullanılması veya dirsek içinin kullanılması; ellerin yıkanması, göz, burun ve ağıza temasının engellenmesi

- $\quad$ Enfekte olmuş kişilerin dokunduğu yerlerin dezenfekte edilmesi

- $\quad$ Et, yumurta ve hayvansal gıdaların iyice pişirilerek tüketilmesi

- Hastalanan kişilerin kalabalıklardan uzak durması, ağız ve burnunu kapatması ve mümkünse tıbbi maske kullanması

Dünya sağlık Örgütü’nün belirlemiş olduğu bu adımlar dikkate alındığında küresel düzeyde ülkelerin pandemiden korunmak amacıyla ilk olarak seyahat yasağı uygulamasını getirdiği söylenebilir. Seyahat yasağı uygulamasında temel amaç hasta bireylerin ve onların temas ettiği herhangi bir kimsenin başka bir ülkeye hastalığı taşımasının engellenmesidir. Hastalığın yayılımını azaltmak amacıyla yürütülen bu uygulama iç politikada ise karantina ve izolasyon uygulamaları ile hayata geçirilmeye çalışılmıştır. Karantina ve izolasyon politikalarında ulaşılmak istenen hedef hasta olan kişilerin hasta olamayanlarla temas etmesinin engellenmesi, hasta bireylerle diğer bireyler temas ettiğinde hastalığın semptomlarını göstermese de toplumdan izole edilmesi ve buna bağlı olarak virüsün yayılmasının kısa vadede engellenmesidir (Carrol ve Jha, 04.10.2020, https://www. theatlantic.com/). Bu uygulamaların yanı sıra ülkelerin pandemi ile mücadelede yürütmüş olduğu bir diğer strateji olabildiğince çok sayıda kişiye test yaparak enfekte kişileri tespit etmektir. Bu strateji salgınla mücadele sürecini yönetmek açısından uygulanan en önemli adımlardan biri olmuştur. Nitekim virüsün ilk yayılım aşamalarında olabildiğince çok sayıda test yapan ülkelerin virüsün yayılımını engelleme konusunda daha başarılı olduğu gözlemlenmektedir (Duran, 2020:9). Bu noktada ülkelerin sahip olduğu test kiti sayıları ve sağlık hizmetlerinin niteliği oldukça önem kazanan konulardan biri olarak karşımıza çıkmaktadır.

Ülkelerin salgınlarla karşılaşma olasılığına karşılık sağlık hizmetlerinin ve planlı öngörülerin yeter düzeyde olması salgın sürecinin yönetilmesinde etkin stratejilerin yürütülmesini kolaylaştıran bir unsur olarak karşımıza çıkmaktadır. Nitekim Covid-19 ile mücadele yürüten ülkelere baktı̆̆ımızda özellikle geçmiş tecrübelere sahip olan ülkelerin bu unsur bağlamında pandemiye daha hazırlıklı olduklarını görmekteyiz. Örneğin Çin, Güney Kore, Hong Kong ve Singapur gibi ülkelerin koronavirüsle mücadelede diğer ülkelere kıyasla daha başarılı olmaları salgınlarla mücadele konusunda yakın dönemde bir takım tecrübelere sahip olmalarından kaynaklanmaktadır. Bunun dışında Uzakdoğu ve Güneydoğu Asya ülkelerinde SARS tecrübesi sonrasında salgınlarla mücadele verme konusunda ilk müdahale merkezleri kurulmuş ve bu merkezlerde kullanılacak olan gerekli araç gereç hazır bir şekilde bulundurulmuştur. Dolayısıyla bu ülkelerde hastalık ile karşılaşıldığı ilk andan itibaren salgınla daha efektif ve proaktif bir mücadele yürütülmesi mümkün kılınmıştır. Ayrıca yakın dönemde tecrübe yaşayan ülkelerin toplumlarının da bu efektif mücadelede oldukça etkin olduğunu söylemek gerekir. Zira geçmiş tecrübelerin 
bilinçlendirdiği toplum alınan önlemlere daha ciddiyetle yaklaşmakta ve sosyal izolasyon bu toplumlarda Batı toplumlarına kıyasla daha başarılı olmaktadır (Duran, 2020:10). Bir örnek vererek ifade etmek gerekirse Çin, Güney Kore ve Hong Kong gibi ülkelerdeki bireylerin virüsün yayıldığı haberi sonrasında kendilerini kalabalıklardan izole ettikleri görülmüş ve bir duyuru ya da zorunluluk olmaksızın kamusal alanlarda maske taktıkları ve hijyen kurallarına uydukları görülmüştür (Duran, 2020:10-11).

Ülkelerin salgınla mücadele kapsamında uyguladıkları diğer stratejilerden biri de salgının uzun vadede yavaşlatılmasına ilişkin uygulanan yöntemlerdir. Bu stratejide yüksek risk grubunda bulunanlar korunmaya çalışılır. Ayrıca bu stratejiyi uygulayan ülkeler virüsün tamamen engellenmesi için sert ve kısıtlayıcı önlemler almak yerine kontrollü ve kademeli önlemler alarak toplumun kitlesel bağışıklık kazanması için çaba göstermektedir. Covid-19 pandemisinin ilk aşamalarında bu stratejiyi uygulayan İngiltere toplumun bağışıklık kazanması için herhangi bir önlem alınmayacağını duyurmuștur. "Sürü bağışıklığı kazandırma" adı verilen bu yöntem uzun vadede bir yavaşlatma hedefine ulaşmaya çalışmaktadır. Fakat Covid-19 hastalığının yayılım süreci ve yarattığı etkiler göz önüne alındığında bu politikanın salgınla mücadelede etkin bir yöntem olmadığına karar verilmiştir (Boyraz, 04.10.2020, https://www.setav.org/). Dolayısıyla İngiltere bu stratejiyi daha sonra terk ederek seyahat yasağı, karantina, sosyal izolasyon gibi politikaları uygulamaya karar vermiştir.

Salgınla mücadelede yürütülen en etkili yöntemlerden bir diğeri ise toplumsal hareketliliğin kısıtlanması ve gündelik hayatta sosyal mesafe kurallarının yaygınlaştırılmasıdır. Toplumsal hareketliliğin kısıtlanması ve sosyal mesafe kurallarının tam olarak uygulanabilmesi için karantina, bazı iş yerlerinin ve okulların kapatılması ve dışarı çıkma yasağının getirilmesi gerekmektedir. Fakat karantina ve sokağa çıkma yasağı uygulamalarının uzun bir süreci ve toplumun her kesimini kapsayamayacak olması devletleri bu uygulamaları kısmi olarak uygulamaya yöneltmiştir. Bununla birlikte koronavirüs ile ilgili bilinçlendirme çalışmaları yapılarak kamusal dirençliliğin arttırılması sağlanmaya çalışılmakta böylece sokağa çıkma yasaklarına gerek kalmadan sosyal mesafe kurallarına dikkat edilerek virüsün yayılımı engellenmeye çalışılmaktadır (TÜBA, 2020).

Görüldügü gibi pandemi ile mücadelede ülkeler her ne kadar farklı yolları tercih etmiş olsa da, ulaşılmak istenen amaç virüs karşısında direnç gösterebilmektir. Bu amaca ulaşabilmek için ülkeler geçmişte yaşanan salgınlardan öğrendikleri karantina, kordon uygulaması, sosyal izolasyon, hijyene dikkat etme gibi yöntemleri uygulamaya başlamıştır. Bununla birlikte değişen küresel sistemde bu uygulamalar risk ve kriz yönetimi çerçevesinde ele alınarak salgınla mücadele yönetimi daha efektif hale getirilmeye çalışılmıştır. Buraya kadar olan süreçte dünya genelinde pandemi ile yürütülen mücadeleleri başlıklar halinde saymak gerekirse bu başlıklar:

- Toplumsal hareketliliği kısıtlama ve sosyal mesafe kurallarının hayata geçirilmesi

- Olabildiğince fazla sayıda test yaparak enfekte kişilerin tespit edilmesi 
- $\quad$ Bireylerin evlerinde kalmalarının sağlanması

- $\quad$ Eğitim kurumlarının kapatılması

- $\quad$ İs yerlerinin kapatılması

- $\quad$ Özel gruplara yönelik tedbirler alınması

- Toplu gösterilerin yasaklanması

- Belli bir bölgenin veya binanın karantina altına alınması

- $\quad$ Kamusal dirençliliği arttırmak için bilinçlendirme çalışmalarının yapılması

- Virüsün günlük yaşamda meydana getirdiği değişimlerin yarattığı sorunların en alt düzeye indirilme çabaları

- Sağlık hizmetlerinin güçlendirilerek nitelikli hale getirilmesi şeklinde sıralanabilir.

Aşağıda verilen tabloda dünya genelinde en yüksek vaka sayılarına sahip olan bazı ülkelerin güncel verilerine yer verilmiştir. Tablo incelendiğinde vaka sayılarının oldukça yüksek olmasından, ayrıca günlük vaka sayılarının Covid-19 salgınının ne kadar devam edeceği bilinemediğinden ülkelerin pandemi ile mücadelelerine devam etmeleri gerektiği düşünülmektedir. 


\begin{tabular}{|l|c|c|c|c|}
\hline Ülke Adı & Toplam Vaka Sayısı & Günlük Vaka Sayısı & Ölüm Sayısı & İyileşen Sayısı \\
\hline ABD & $7,48 \mathrm{MN}$ & +154 & $214 \mathrm{~B}$ & $4,8 \mathrm{MN}$ \\
\hline Hindistan & $6,69 \mathrm{MN}$ & $+4,111$ & $104 \mathrm{~B}$ & $5,58 \mathrm{MN}$ \\
\hline Brezilya & $4,94 \mathrm{MN}$ & $+11,946$ & $147 \mathrm{~B}$ & $4,26 \mathrm{MN}$ \\
\hline Rusya & $1.23 \mathrm{MN}$ & $+10,888$ & 21,475 & 982,324 \\
\hline Kolombiya & $862 \mathrm{~B}$ & +7.106 & 26.844 & 761,674 \\
\hline Peru & $828 \mathrm{~B}$ & +1.830 & 32.742 & 706,223 \\
\hline İspanya & $813 \mathrm{~B}$ & +23.480 & 32.225 & 150.376 \\
\hline Meksika & $790 \mathrm{~B}$ & +28.115 & 81.877 & 550,053 \\
\hline Arjantin & $751 \mathrm{~B}$ & - & 16.937 & 636,672 \\
\hline Güney Afrika & $682 \mathrm{~B}$ & +926 & 17.016 & 614,781 \\
\hline Fransa & $624 \mathrm{~B}$ & - & 32.299 & 97,778 \\
\hline Birleșik Krallık & $516 \mathrm{~B}$ & - & 42.369 & 780 \\
\hline İran & $476 \mathrm{~B}$ & +3902 & 27.192 & 389,966 \\
\hline Şili & $472 \mathrm{~B}$ & +1567 & 13.037 & 442,070 \\
\hline Irak & $383 \mathrm{~B}$ & - & 9.464 & 312.158 \\
\hline Bangladeș & $370 \mathrm{~B}$ & - & 5.375 & 283,182 \\
\hline Suudi Arabistan & $337 \mathrm{~B}$ & - & 4.898 & 322.055 \\
\hline İtalya & $328 \mathrm{~B}$ & - & 36.002 & 232.681 \\
\hline Türkiye & $326 \mathrm{~B}$ & +1603 & 8.498 & 286.370 \\
\hline Filipinler & $325 \mathrm{~B}$ & - & 5.840 & 273,123 \\
\hline Pakistan & $316 \mathrm{~B}$ & +644 & 6.523 & 300.616 \\
\hline Endonezya & $307 \mathrm{~B}$ & +3.622 & 11.253 & 232.593 \\
\hline Almanya & $305 \mathrm{~B}$ & +3.100 & 9.554 & 263.700 \\
\hline İsrail & $272 \mathrm{~B}$ & +4.579 & 1.757 & 208.763 \\
\hline Ukrayna & $230 \mathrm{~B}$ & - & 4.430 & 103.401 \\
\hline
\end{tabular}

Tablo 1.2. : Covid-19 Dünya Verileri: Vaka Sayısının En Yüksek Olduğu Ülkeler

Kaynak: https://www.covidvisualizer.com/

Güncel Covid-19 vaka sayılarına erişmek için bkz. https://covid19.who.int/

Ülkelerin pandemi ile yürüttüğü mücadele yöntemlerinin genel çerçevede tartışıldı̆̆ 1 bu bölümde her bir devletin veya uluslararası örgütün uyguladığı stratejik adımlar araştırmanın kısıtlılı̆̆ı nedeniyle değerlendirmeye alınmamıştır. Nitekim bu konu pandemi ile mücadelede karşılaştırmalı yöntemler konusu dahilinde ele alınmalıdır. Bununla birlikte çalışmamızın odak noktasını oluşturan pandemi ile mücadelede politika önerileri sonucuna ulaşabilmek için pandemi ile mücadelenin Türkiyede ne şekilde yürütüldügü konusu ayrıntılı olarak ele alınmalıdır. Bu doğrultuda devam eden bölümde Türkiye'de pandemi ile mücadele yöntemleri konusu tartışılacaktır. 


\subsection{Türkiye'de Covid-19 Pandemisi}

Türkiye koronavirüs ile mücadeleye ülke içerisinde ilk vakanın görüldüğü 10 Mart tarihinden çok önce başlamıştır. Türkiye’nin yürütmüş olduğu mücadele yöntemleri, 2009 yılında ortaya çıkan H1N1 pandemisinde meydana gelen sorunların temel alınarak hazırlandığı Pandemik İnfluenza Ulusal Hazırlık Planı çerçevesinde şekillenmiştir (Sertdemir, 2020:19). Koronavirüs tehdidinin ortaya çıtğg ve diğer ülkelerin henüz bir tedbir almadığı salgının ilk aşamalarında Türkiye bu plan doğrultusunda otuz uzmandan oluşan Koronavirüs Bilim Kurulunu kurmuştur. Salgının yaygınlaşmasından önce hazırlanan hazırlık planında öncelikle demografik bulgular iyileştirilmeye çalışılmıştır. Bu doğrultuda bu hazırlık planında hasta yönetimindeki eksiklikler yenilenmeye çalışılmış, laboratuvar ve insan kaynağı kapasitelerinin artırılması hedeflenmiş, organizasyonel yapıların oluşturulması ve iletişim stratejilerinin iyileştirilmesi amaçlanmıştır (T.C. Sağlık Bakanlığı, 2019). Ayıca hazırlık planında risk ve kriz yönetimi bağlamında plan, planlama ve koordinasyon, durumun izlenmesi ve değerlendirilmesi, koruma ve kontrol, tıbbi uygulamalar ve iletişim başlıkları altında izlenecek birtakım politikalar belirlenmiştir (Duran, 2020:18).

Türkiye bu planlı hazırlık çalışması doğrultusunda virüsün yayılımını engellemek için seyahat kısıtlaması uygulamasını kullanan ilk ülkelerden biri olmuştur. 21 Ocak’tan itibaren havaalanlarında tedbir almaya başlayan Türkiye, 22 Ocak’ta ise Wuhan-İstanbul uçuşlarını durdurmuş, 5 Şubat’tan itibaren ise Çin'den gelen tüm uçuşlara son vermiştir. 23 Şubat tarihinde ise Türkiye-İran sınırı kapatılmış ve yurt dışı seyahatleri kademeli olarak azaltılmış, 27 Mart tarihinde tüm uçuşlar durdurulmuştur (Budak ve Korkmaz, 2020:72).

Pandemi ile mücadele sürecinde Türkiye sağlık alanında da gerekli tedbirleri almaya çalışmıştır. Bu doğrultuda öncelikle olabildiğince fazla sayıda test yapma çalışmaları hızlandırılmış, yerli test kitleri üretilerek test sonuçlarının daha hızlı bir şekilde çıkması sağlanmıştır. Daha sonra referans hastaneler belirlenerek bu hastanelerde izolasyon odaları oluşturulmuş, sağlık çalışanı sayıları arttırılmış ve eczane hizmetlerinde gerekli araç-gereç temin edilmeye çalışılmıştır.

Pandemi ile mücadelede eğitim alanında yürütülen politikalara bakıldığında öncelikle sosyal izolasyonun sağlanabilmesi için 16 Marttan itibaren ilk ve ortaokullar tatil edilmiş daha sonra Mart ayı içerisinde uzaktan eğitim ile okullara devam edilmesi kararlaştırılmıştır. Yeni eğitim-öğretim yılı döneminde ise 21 Eylül tarihinden itibaren ilkokul 1. Sınıf öğrencileri örgün eğitime başlamış ve kademeli bir şekilde diğer sınıflar da örgün eğitim sistemine yeniden dönmek üzere uzaktan eğitim ile devam etmektedir.

Ekonomik tedbirler kapsamında bakıldığında ilk olarak 100 milyar liralık bir ekonomi paketi açıklanmış, daha sonra bu tedbir paketi kapsamında emekli aylıklarının arttırılması, ihtiyaç sahiplerine toplamda 2 milyar liralık yardım yapılması, en düşük emekli maaşının bin beş yüz liraya çıkarılması ve bayram ikramiyelerinin erken ödenmesi gibi birtakım politikalar yürütülmeye çalışılmıştır. 
Türkiye pandemi ile mücadele sürecinde sosyal ve ekonomik anlamda birtakım stratejiler belirleyerek her alanda bu mücadeleyi yürütmeye çalışmıştır. Bununla birlikte sosyal mesafe kurallarının efektif bir şekilde uygulanabilmesi için sosyal ve kültürel etkinlikler ertelenmiş, şehirlerarası yolculuk yapmak valilik iznine bağlanmış, spor liglerine ara verilmiş, camilerde toplu ibadet etme yasağı getirilmiş, piknik ve park alanları kamuya kapatılarak bireylerin sosyal izolasyonu sağlanmaya çalışılmıştır. Ayrıca sokağa çıkma yasağı, karantina uygulamaları, "Hayat Eve Sığar ve Evde Kal" kampanyaları ve "Koronavirüs Riskine Karşı 14 Kural, Ellerimizi Ne Zaman Yıkamalıyı??” gibi kamu spotu uygulamaları ile kamu bilinçlendirmesinin sağlanması ve bunun sonucunda sosyal izolasyonun toplumun tümünde aynı ciddiyetle algılanması sağlanmaya çalışılmıştır (T.C. Sağlık Bakanlı̆̆ , 2020) Arslan ve Karagül, 2020:11-12).

Gerek küresel düzeyde gerekse yerel düzeyde ülkelerin pandemi ile yürüttükleri mücadele ve yeni vaka sayıları ile ilgili güncel veriler göz önüne alındığında, Covid-19 hastalığına karşı ülkelerin daha etkili ve proaktif bir mücadele süreci yönetmesi gerektiği düşünülmektedir. $\mathrm{Bu}$ bağlamda ülkelerin pandemi ile ilgili mücadele yöntemlerini risk ve kriz yönetimi çerçevesinde ayrıca ele almaları gerekmektedir. Dolayısıyla devam eden bölümde risk ve kriz bağlamında pandemi ile daha aktif bir mücadele yönetimi gerçekleştirmek için bir takım politika önerilerinde bulunulacaktır.

\section{SALGINLARLA MÜCADELEDE POLITIKKA ÖNERİLERİ}

Küresel olarak mücadele vermek zorunda kaldı̆̆ımız Covid-19; sosyal, kültürel ve ekonomik alanlar başta olmak üzere hayatın her alanında bir takım değişim ve dönüşümlere yol açmıştır. Tehlikenin küresel boyutta olması ülkeler arasında iyi bir iletişim yönetimini gerektirirken aynı şekilde ülke içerisinde de toplum ve hükümetler arasındaki iletişim yönetimi daha etkin şekilde yürütülmesini gerektirmektedir. Bu doğrultuda küresel yönetişimi büyük ölçüde değiştiren ve dönüştüren Covid-19 ile tüm dünya ülkeleri bir takım strateji ve taktikler doğrultusunda mücadele etmek durumunda kalmışlardır. Ne var ki salgınlarla mücadele için yakın dönemlerde yapılan hazırlık çalışmaları ve planları olmasına rağmen Covid-19'un ilerleyişi bu hazırlık çalışmalarının yeterli düzeyde etkin olmadığını göstermiştir. Nitekim virüs ile ilk karşılaşılan dönemlerde gerek bireylerin gerek ülkelerin bir karmaşa içerisinde hareket ettiklerini görmekteyiz. Öte yandan hastalık ile ilgili ilk tanınma gerçekleştikten sonra hastalıkla mücadele adım adım daha kontrollü hale gelmiştir. Geçmiş salgınlardan edinilen tecrübeler pandemi ile mücadelede referans alınan en önemli kaynaklar olmakla birlikte, içerisinde yaşadığımız çağ salgın yönetimi konusuna çok boyutlu ve proaktif bir süreci yönetmeyi gerektirmektedir. Bu doğrultuda bu bölümde salgın yönetimi ile yürütülen mevcut politikalar dikkate alınarak bir takım politika önerilerinde bulunulacaktır.

- $\quad$ İlk olarak salgınlarla mücadele; salgın öncesi, salgın esnasında ve salgın sonrasında olmak üzere üç aşamada değerlendirilmelidir. 
- $\quad$ İlk aşama, yani salgın öncesinde salgınlarla mücadelede alınan önlem veya eylem planlarının bir hazırlık çalışması çerçevesinde ele alınması gerekmektedir. Dolayısıyla mevcut ve geçmiş tecrübelerden elde verilerle, alanında uzman kişilerden oluşan çalışma gruplarıyla öngörülebilir salgın veya doğal afet durumları tespit edilmeli ve bu doğrultuda gerekli araç-gereç ve mali kaynak alt yapısı güçlendirilmelidir. Öte yandan geliştirilen ulusal pandemi planları mevcut duruma göre güncellenerek geliştirilmelidir. Ayrıca bu aşamada yürütülecek eylemler risk (tehlikenin varlığı) bağlamında ele alınmalıdır.

İlk aşama ile ilgili olarak meydana gelen salgınların engellenmesi adına çalışmalar yürütülmeli ve bu çalışmaların önceliği küresel düzeyde "doğaya müdahaleci yaklaşımların önlenmesi ve çevreci politikalara önem verilmesi” olmalıdır. Bununla birlikte yerel düzeyde kentleşme politikalarının doğa ile uyumu gözetilerek planlanması gerekmektedir. Öte yandan kamusal düzeyde toplumun her kesimi bilinçlendirilmeli ve Aydın ve Belli (2017:3)'nin ifade ettiği gibi canlı merkezci çevre politikaları yaklaşımı çerçevesinde "doğaya muhtaç insan" algısı yeniden yaratılmalıdır.

- Salgınların engellenmesi adına aşı çalışmaları, antimikrobik madde geliştirme çalışmaları, biyolojik savaş tehdidini izleme ve tespit çalışmaları ve tüm bunlarla birlikte küresel ısınma ve iklim değişikliklerinin yaratacağı enfeksiyon hastalıkların önlenmesi adına çalışmalar yapılmalıdır.

İkinci aşama olarak değerlendirilen salgın esnasında uygulanacak politikalar ise alanında uzman kişilerin tespit ve verileri doğrultusunda belirlenmeli ve yine bu uzmanların gözetiminde yürütülmelidir. Salgın hastalık durumunda hastalığın tanısından sonra belirlenen uygun politikalar hem ulusal düzeyde hem de küresel düzeyde uygulanmalıdır. Bu doğrultuda pandemik salgınların büyük çoğunluğunun hava yolu ile bulaştığg göz önüne alındığında iklimlendirme çalışmalarına önem vermek gerekmektedir (Öztürk, 2020:87).

- Yapılan literatür araştırması doğrultusunda geçmişten günümüze farklılaşarak taşınan ve salgın durumlarında kafa karışıklığına neden olduğunu tespit ettiğimiz bir olgudan söz etmek ve bu olguyla ilgili olarak politika önerilerinde bulunmak yerinde olacaktır. Tarihten günümüze salgınlar incelendiğinde, insanların salgın hastalıkları Tanrı tarafından gönderilen bir ceza veya lanetlenme olarak algıladıklarını görmekteyiz. Bununla birlikte tarihte birçok salgında bu düşünceyi benimseyen insanların bilimsel müdahalelerin yapılmasını engellediklerini ve dogmatik bilgilerle hareket ederek sürece zarar verdikleri var olan bir gerçekliktir. Bugün ise insanlığın aynı durumun farklılaşan bir yönü ile karşı karşıya olduğunu ifade etmek yanlış olmayacaktır. Nitekim bugün insanlar arasında Covid-19 hastalığı hakkında, hastalığın bir komplo teorisinden ibaret olduğunu veya laboratuvar ortamında üretilmiş bir virüs ile bir biyolojik saldırı hedeflendiğini düşünenler vardır. Bu iki durum ele alındığında temelde aynı kökenden gelen durumların varlığını fakat günümüzde farklılaşan taraflarıyla karşımıza çıktığını görmekteyiz. Dolayisıyla Covid-19 pandemisiyle verilen mücadeleye zarar verebilecek bir durum olarak komplo teorileri üzerinde ayrıca çalışmalar yapmak gerekmektedir. 
Pandemi ile mücadele veren tüm ülkeler gerekli bilinçlendirme çalışmalarını nitelikli hale getirmeli ve toplumun her kesiminin durumun ciddiyetini anlaması sağlanmalıdır.

- Ayrıca ülkelerin bilinçlendirme politikalarına küresel iletişimin güçlendiği günümüzde daha da önem verilmelidir. Açık kaynaklardan elde edilen bilgilerin bireyleri yanlış yönlendirmesine izin verilmemeli ve bu durum bilgi yönetimi bağlamında ayrıca ele alınmalıdır.

- Şimdiye kadar bahsedilen tüm öneriler gerek küresel düzeyde gerek yerel düzeyde bir hazırlık ve mücadele yöntemlerini içermektedir. Fakat dikkate alınması gereken bir diğer nokta pandemik salgınların sosyal ve ekonomik yaşamda neden olduğu olumsuz etkiler ve bunların minimum düzeye indirilmesidir. Salgın veya doğal afet dönemlerinde kamusal dirençliliği arttırmak ise ancak sosyal politikalara verilen önem ile mümkün olmaktadır. Bu bağlamda hükümetlerin hem salgın öncesi planlamalarda hem de salgın esnasında yoksullukla mücadele kapsamında kapsamlı bir faaliyet yürütmesi gerekmektedir. Önen (2010a:71) bu noktada merkezi yönetimlerin olduğu kadar yerel yönetimlerin de hayati önem taşıdığını ifade etmektedir. Ayrıca Önen (2010:170) yoksullukla mücadelede yerel yönetimlerin merkezi yönetimlerle işbirliği içerisinde olmasının, merkezi yönetimden kaynaklanan bir takım sorunları ortadan kaldıracağını ifade etmektedir. Bu noktada tüm dünya hükümetlerinin sosyal politikalarını güçlendirmelerini ve insan onuruna yakışacak saygın bir hayatı mümkün kılması gerektiğini söylemek gerekir.

- Sosyal politikalar konusu dahilinde göç ve göç yönetimi konusunu da ele almak gerekir. Zira içinde bulunduğumuz pandemi döneminde göç hareketleri ve göçmenlerin durumları sıklıkla gündeme gelen konulardan biri olmuştur. Ayrıca salgın hastalıklar nedeniyle geçmişte de zorunlu kitlesel göçler yaşanmış ve bu durum gerek göç edenler açısından gerekse göç edilen yerler açısından birtakım problemlerin yaşanmasına neden olmuştur (Ağır, 2018:114). Dolayısıyla kitlesel hareketlerin yaşanmasını ve bu yolla salgın hastalığın yayılmasını engellemek amacıyla uluslararası işbirliği içerisinde politikalar geliştirilmelidir.

- Son olarak uygulanan mevcut politikalar ve önermiş olduğumuz politikaların risk ve kriz yönetimi çerçevesinde ele alınması hayati derecede öneme sahiptir. Tecrübe edindiğimiz üzere salgınlar da bir yönetim sürecini gerektirmektedir. Bu yönetim süreci ait olduğu koşullara özel olarak genişletilmeli, farklı yönetim perspektifleri açısından değerlendirilmelidir. Nitekim içerisinde bulunduğumuz pandemik salgın; stratejik anlamda risk, kriz, bilgi ve göç yönetimi gibi çok boyutlu olarak ele alınmalı ve her yönü ile salgın değerlendirilmelidir.

\section{SONUÇ}

Geçmişten günümüze salgınlar değerlendirildiğinde, insanlık tarih boyunca pek çok 
ölümcül salgınla mücadele etmek zorunda kalmıştır. Ayrıca hem geçmişten alınan referansla hem de günümüzde yürütülen çalışmalar gelecek yıllarda da insanlığın salgınlarla mücadele etmek zorunda kalacağını göstermektedir. Etkileşim ve iletişimin giderek daha yoğun ve güçlü hale geldiği dünyamızda bu salgınların doğurduğu olumsuz sonuçların da aynı oranda etkili ve güçlü olduğunu görmekteyiz. Dolayısıyla modern toplumlarda salgınla mücadele yöntemleri geleneksel toplumlarda olduğundan farklılaşarak karşımıza çıkmaktadır. Özellikle gündelik yaşamın pratiklerine kadar etki eden güçlü bir salgının yeni yönetim yaklaşımları çerçevesinde ele alınması, salgının yaratacağı zararları en alt düzeye indirmek açısından önemlidir. Nitekim tüm dünyayı sağlık, ekonomi, sosyal yaşam, siyaset ve uluslararası ilişkiler başta olmak üzere pek çok yönden etkileyen Covid-19 pandemisi çok boyutlu mücadele stratejilerini gerektiren bir salgın hastalık türü olarak karşımıza çıkmıştır. Hala etkilerini sürdürerek devam eden Covid-19 ile bütüncül bir mücadele yöntemi geliştirmek için risk, kriz, bilgi ve göç yönetimi çalışmalarının salgın açısından ele alınması gerekmekte, bununla birlikte çevreci politikalar ve kentleşme politikaları daha sistemli şekilde yürütülmelidir. 


\section{KAYNAKÇA}

Ağır, Osman (2018). “Türkiye’deki Suriyelilere Sağlanan Kamusal Hizmetlere Yönelik Bir Değerlendirme”, Kahramanmaraş Sütçü İmam Üniversitesi İİBF Dergisi, 8(2): 111 128.

Akdur, Recep (2006). “Sıtma ve Sıtma Salgınları Tarihi”, Bilim Tarihi Araştırmaları, Sayı:2: 11.

Akyay, Necmettin (1974). "Türkiye'de Veba Salgınları ve Veba Hakkında Eski Yayınlar”, Mikrobiyoloji Bülteni, 8(2): 209-219.

Arık, F.Ş., 1991. “Selçuklular Zamanında Anadolu’da Veba Salgınları”, Tarih Araştırmaları Dergisi, 15(26): 27-57.

Arslan, İbrahim ve KARAGÜL, Soner (2020). "Küresel Bir Tehdit (Covid-19 Salgını) ve Değişime Yolculuk”, Üsküdar Üniversitesi Sosyal Bilimler Dergisi, (10): 1-36.

Aslan, Recep (2020). “Tarihten Günümüze Epidemiler, Pandemiler ve Covid-19”, Ayrıntı Dergisi, 8(65): 35-41.

Aşkın, Rüstem, BOZKURT, Yasemin ve ZEYBEK, Zekiye (2019). "Covid-19 Pandemisi Psikolojik Etkileri ve Teröpotik Müdahaleler”, İstanbul Ticaret Üniversitesi Sosyal Bilimler Dergisi, 37(Özel Ek): 304-318.

Ataç, Adnan ve UÇAR, Muharrem (2006). “Önemli Bulaşıcı Hastalıklar ve Yaşam Sürelerine Etkileri”, Bilim Tarihi Araştırmaları: Salgın Hastalıklar Tarihi, Sayı:2: 3342.

Ayar, Mesut (2005). “Osmanlı Devleti’nde Kolera Salgını İstanbul Örneği (1892-1895”, Doktora Tezi, İstanbul: Marmara Üniversitesi Türkiyat Araştırmaları Enstitüsü.

Aydın, Abdullah ve BELLİ, Aziz (2017). "Kamu Yönetimi Bölümlerindeki Çevre Derslerinin Çevre Bilinci Üzerine Etkisi”, Yüzüncü Yıl Üniversitesi Sosyal Bilimler Enstitüsü Dergisi, 1(Özel Say1-4): 13s.

Beck, Ulrich (2019). Risk Toplumu: Başka Bir Modernliğe Doğru, İstanbul: İthaki Yayınları.

Boyraz, Hacı Mehmet (2020). “5 Soru: Koronavirüs Salgını ve İngiltere”, https://www. setav.org/5-soru-koronavirus-salgini-ve-ingiltere/ingiltere-kor on avir us-salgini/, (04.10.2020).

Budak, Fatih ve KORKMAZ, Şerif (2020). “COVID-19 Pandemi Sürecine Yönelik Genel Bir Değerlendirme: Türkiye Örneği”, Sosyal Araştırmalar Dergisi, (1): 62-79. 
Buzgan, Turan ve GÜNER, Öner (2020). “Dünya Sağlik Örgütü’nün Pandemilerdeki Etkinliği ve Post-Pandemik Dönemdeki Geleceği”, Küresel Salgının Anatomisi: İnsan ve Toplumun Geleceği, Ed.: M. Şeker, A. Özer, C. Korkut, Türkiye Bilimler Akademisi, Ankara, 131-148.

Cadoğlu, Kemali (2000). Risk Yönetimi ve TSK'daki Uygulamalar, İstanbul: Harp Akademileri Yayınları.

Cener, Pınar (2007). "Kriz Yönetimi”, http://danismend.com/kategori/altkategori/krizyonetimi-1/, (22.08.2020).

Diamond, Jared (2018). Tüfek, Mikrop ve Çelik, Çev.: Ü. İnce, İstanbul: Pegasus Yayınları.

Dikmen, UĞRAŞ, Asiye, KINA, Hatice Mediha, ÖZKAN, Seçil, İLHAN, Mustafa Necmi (2020). "COVID-19 Epidemiyolojisi: Pandemiden Ne Öğrendik" ,Journal of Biotechnology and Strategic Health Research, 1(Özel Sayı): 29-36.

Dinçol, Mustafa Ali (1985). "Ashella Rituali (CTH 394) ve Hititlerde Salgın Hastalıklara Karşı Yapılan Majik İşlemlere Toplu Bir Bakış”, Türk Tarih Kurumu Belleten, XLIV, Say1: 193: 40s.

Duran, Hazal (2020). Devletlerin Koronavirüsle Karşılaştırmalı Mücadele Stratejileri, İstanbul: SETA Yayınları.

Emhan, Abdurrahim (2009). "Risk Yönetim Süreci ve Risk Yönetmekte Kullanılan Teknikler”, Atatürk Üniversitesi İktisadi ve İdari bilimler Dergisi, 23(3): 209-220.

Giddens, Antony (1999). "Risk", BBC News, http://news.bbc.co.uk/hi/english/static/ events/reith_99/week2/week2.htm, (22.08.2020).

Günata, Gülşah, (2020). “Büyük Atina Vebası Demokrasinin Çöküşünü Hazırladı”, https:// arkeofili.com/buyuk-atina-vebasi-demokrasinin-cokusunu-hazirladi/, (22.09.2020).

Hays, J. N., (2005). Epidemics and Pandemics: Their Impacts on Human History, California: ABC-CLIO.

Hays, J.N. (1998). The Burdens of Disease: epidemics and Human Response in Western History, New Jersey: Rutgers University Press.

İnand1, Tacettin, SAKARYA, Sibel, ÜNAL, Belgin ve ERGİN, Işıl (2020). “COVID-19 Salgını Özelinde Karar Vericiler için Risk Değerlendirme Yaklaşımı”, Sağlık ve Toplum Dergisi (Özel Sayı): 27-38.

Jarus, Owen (2020). "20 of The Worst Epidemics and Pandemics in History", https://www. livescience.com/worst-epidemics-and-pandemics-in-history.html, (22.09.2020). 
John Hopkıns Unıversity, (2020). "COVID-19 Dashboard by the Center for Systems Science and Engineering at John Hopkins University”, https://coronavirus.jhu.edu/ map.html, (30.09.2020).

Kılıç, Orhan (2020). “Tarihte Küresel Salgın Hastalıklar ve Toplum Hayatına Etkileri”, Küresel Salgının Anotomisi: İnsan ve Toplumun Geleceği, Ed.: M. Şeker, A. Özer ve C. Korkut, Ankara: Türkiye Bilimler Akademisi.

Köse, Hüseyin (2007). "Yeni Risk Tanımlamaları Bağlamında Küresel Medya”, Selçuk İletişim, 5(1): 42-51.

Önen, Mustafa, Semih (2010). "Yoksulluk ve Yerinden Yönetim: Nasıl Bir Yöneti(şi)m?”, Türk İdare Dergisi, 18(469): 165-182.

Önen, Mustafa, Semih (2010a). "Yerel Yönetimlerin Yoksullukla Mücadelesi: Malatya Belediyesi Örneği”, Sayıştay Dergisi, (Sayı:79): 63-95.

Özdemir, Hikmet (2005). Salgın Hastalıklardan Ölümler: 1914-1918, Türk Tarih Kurumu.

Özer, Mehmet Akif (2011). 21. Yüzyılda Yönetim ve Yöneticiler, Ankara: Nobel Basım Yayın.

Sertdemir, Ayşe (2020). “Türkiye’nin Koronavirüsle Mücadele Performansı Üzerine Bir Değerlendirme”, Nazilli İİF Dergisi, 1 (1): 15-26.

Sezgin, Ferudun (2003). “Kriz Yönetimi”, Gazi Üniversitesi Sosyal Bilimler Dergisi, 4(8): 181-195.

T.C. Sağlık Bakanlığı, (2020). “Kontrollü Sosyal Hayat”, https://www.trthaber.com/haber/ gundem/bakan-koca-acikladi-kontrollu-sosyal-hayat-donemi-basliyor-482213.html, (04.10.2020).

TBD Kamu-BİB, 2006. “Bilişim Teknolojilerinde Risk Yönetimi”, 2. Çalışma Grubu, Kamu Bilişim Platformu VIII, 66s.

TDK (Türk Dil Kurumu) (2020). “Risk” https://sozluk.gov.tr/, (21.08.2020).

Temel, Mustafa Kemal (2012). “1918 Grip Pandemisi”, Yüksek Lisans Tezi, İstanbul: İstanbul Üniversitesi Sağlık Bilimleri Enstitüsü.

Thucydides, (2019). Peloponnessos Savaşları, Çev.: F. Akderin, Belge Yayınları.

Topuz, Ercüment (2020). "XIX. Van'da İllet-i Kolera ile Mücadelede Usul-i Karantina ve Kordon Uygulaması, Van Yüzüncü Yıl Üniversitesi Sosyal Bilimler Dergisi, (Sayı: 48): 297-316. 
Tunç, Ahmet, AĞIR, Osman, BELLİ, Aziz ve ÖZDEMİR, Fatma Nur (2018). "Yönetimde Yeni Bir Yaklaşım Olarak Kriz Yönetimine Teorik Bir Bakış", VII. Uluslararası Sempozyum İdealden Gerçeğe Toplum, Siyaset ve Ekonomi, Malatya, 82-89.

Turan, Abdülmenaf ve ÇELİKYAY HAMZA, Hicran (2020). “Türkiyede Kovid-19 ile Mücadele: Politikalar ve Aktörler”, Uluslararası Yönetim Akademisi Dergisi, 3(1): $1-25$.

TÜBA (Türkiye Bilimler Akademisi), (2020). COVİD-19 Pandemi Değerlendirme Raporu, Türkiye Bilimler Akademisi Yayınları, Rapor: 34, 159s.

Uludağ, Osman Şevki (1938). “Son Kapitülasyonlardan Biri: Karantina”, Türk Tarih Kurumu, 2 (7-8): 445-467.

Ünsal, Utku; EREN, Nevzat ve BENLİ, Doğan (1982). “Sitma Epidemiyolojisi”, Hacettepe Üniversitesi Toplum Hekimliği Enstitüsü.

Üstün, Çağatay ve ÖZÇİFTÇİ, Seçil, (2020). “Covid-19 Pandemisinin Sosyal Yaşam ve Etik Düzlem Üzerine Etkileri: Bir Değerlendirme Çalışması”, Anadolu Kliniği Tip Bilimi Dergisi, 25(1): 143-153.

WHO, (2020). "Naming the Coronavirüs Disease (Covid-19) and the Virüs That Causes It", https://www.who.int/emergencies/diseases/novel-coronavirus-2019/technicalguidance/naming-the-coronavirus-disease-(covid-2019)-and- the-virus-thatcauses-it, (30.09.2020).

Yılmaz, Özgür (2017). “1847-1848 Kolera Salgını ve Osmanlı Coğrafyasındaki Etkileri”, Avrasya İncelemeleri Dergisi, 6(1): 23-55.

Yin, Yudang ve WUNDERİNK, Richard (2018). "MERS, SARS and Other Coronaviruses as Causes of Pneumonia”, Respiratory İnfections in the Asia-Pacific Region, (23): 130137.

Yolun, Murat (2012). “İspanyol Gribinin Dünya ve Osmanlı Devleti Üzerindeki Etkileri”, Yüksek Lisans Tezi, Adıyaman Üniversitesi Sosyal Bilimler Enstitüsü, Adıyaman. 